MECHANISMS IN ENDOCRINOLOGY

\title{
A sense of time of the glucocorticoid circadian clock: from the ontogeny to the diagnosis of Cushing's syndrome
}

\author{
Ayrton Custodio Moreira', Sonir Rauber Antonini' ${ }^{\mathbf{2}}$ and Margaret de Castro ${ }^{1}$ \\ Departments of ${ }^{1}$ Internal Medicine and ${ }^{2}$ Pediatrics, Ribeirao Preto Medical School, University of Sao Paulo, Ribeirao \\ Preto, Sao Paulo, Brazil
}

\author{
Correspondence \\ should be addressed \\ to A C Moreira \\ Email \\ acmoreir@fmrp.usp.br
}

\begin{abstract}
The circadian rhythm of glucocorticoids has long been recognised within the last 75 years. Since the beginning, researchers have sought to identify basic mechanisms underlying the origin and emergence of the corticosteroid circadian rhythmicity among mammals. Accordingly, Young, Hall and Rosbash, laureates of the 2017 Nobel Prize in Physiology or Medicine, as well as Takahashi's group among others, have characterised the molecular cogwheels of the circadian system, describing interlocking transcription/translation feedback loops essential for normal circadian rhythms. Plasma glucocorticoid circadian variation depends on the expression of intrinsic clock genes within the anatomic components of the hypothalamic-pituitary-adrenal axis, which are organised in a hierarchical manner. This review presents a general overview of the glucocorticoid circadian clock mechanisms, highlighting the ontogeny of the pituitary-adrenal axis diurnal rhythmicity as well as the involvement of circadian rhythm abnormalities in the physiopathology and diagnosis of Cushing's disease.
\end{abstract}

\section{Introduction}

Circadian rhythms have been widely observed in various organisms spanning from cyanobacteria to humans. Circadian clocks have adopted geophysical cycles as part of predictive homeostasis, thereby preparing living organisms for environmental fluctuations and regulating sleep patterns, feeding behaviour, body temperature, blood pressure and hormone release $(1,2)$.

\section{Invited Author's profile}

Ayrton Custodio Moreira, MD, PhD is Prof. of Medicine at the Division of Endocrinology and Metabolism, Department of Internal Medicine, Ribeirao Preto Medical School, University of Sao Paulo, Brazil. He has published more than 150 papers in high-quality journals and has held several important administrative positions, including the Dean of the Ribeirao Preto Medical School. In recognition of his outstanding contributions as an educator and researcher, he has received many medical education awards. His main research interest includes the physiology and pathophysiology of the pituitary-adrenal axis, focusing on the glucocorticoid circadian rhythm and the diagnosis of Cushing's syndrome.

(C) 2018 European Society of Endocrinology Printed in Great Britain
Published by Bioscientifica Ltd. 
The glucocorticoid circadian rhythm in humans had been first described by Pincus in the early 1940s as a diurnal rhythm based on the excretion of urinary ketosteroids (3). Later, the diurnal rhythmicity of the pituitaryadrenal axis had been confirmed in studies involving rats (4) and other mammals, including healthy humans (5). The lack of a diurnal rhythm for plasma and urinary 17-hydroxycorticoid levels in patients with Cushing's syndrome had been first described during the mid-to-late 1950s $(6,7)$. At that time, Halberg (8) introduced the term 'circadian', which means approximately $24 \mathrm{~h}$, to denote daily cycles. The author adopted the terminology from the oscillation theory in physics to describe biological circadian rhythms in terms of their mean levels (Mesor), amplitude, peak, trough (nadir), phase and antiphase. He also coined the concept of environmental synchronisers (zeitgebers) and introduced cosinor-based rhythmometry $(9,10)$.

Studies regarding postnatal emergence of glucocorticoid circadian rhythmicity, both in rats $(11,12)$ and humans $(13,14)$, had surfaced during the 1960s. Although Halberg (8) suggested that 24-h rhythms may be related to the transmission of cyclic genetic information from DNA to RNA, the nature of the underlying oscillations remained unknown until 1971, when Konopka and Benzer described the first clock gene Period (Per) at the period locus on the $\mathrm{X}$ chromosome of Drosophila melanogaster. Per locus mutations induced alterations in pupal eclosion and adult activity rhythms, including courtship singing (15).
During the 1980s, Young, Hall and Rosbash, recipients of the 2017 Nobel Prize in Physiology or Medicine, began molecular mapping studies on the Per locus of Drosophila while identifying news transcripts $(16,17)$. In addition, they observed a feedback loop that enabled Per-encoded proteins to cycle their own RNA (18). Searching for genes regulating circadian rhythms in mammals, Takahashi's group identified a new gene named Clock (Circadian Locomotor Output Cycles Kaput), which is essential for normal circadian behaviour (19). Since the mid-1990s to the present, several studies have shown cell-autonomous molecular mechanisms for circadian rhythms. These circuits involve at least ten clock genes and their transcript proteins connected by feedback loops, characterising molecular circadian cycles that oscillate at a periodicity of approximately $24 \mathrm{~h}(20,21,22)$.

\section{The mammalian molecular clock mechanism}

Clock genes are expressed in essentially all mammalian cells (22). The cogwheels of the circadian timekeeping system consist of two interlocking transcription/translation feedback loops: a core loop supported by an accessory loop. The circadian molecular clock system in mammals has been extensively reviewed elsewhere $(22,23,24,25)$ with its model being summarised in Fig. 1. Briefly, the core loop comprises circadian genes Clock and Bmal1 (Arntl), Periods (Per1, Per2 and Per3) and cryptochromes (Cry1 and Cry2). The principal mechanism for the circadian timekeeping

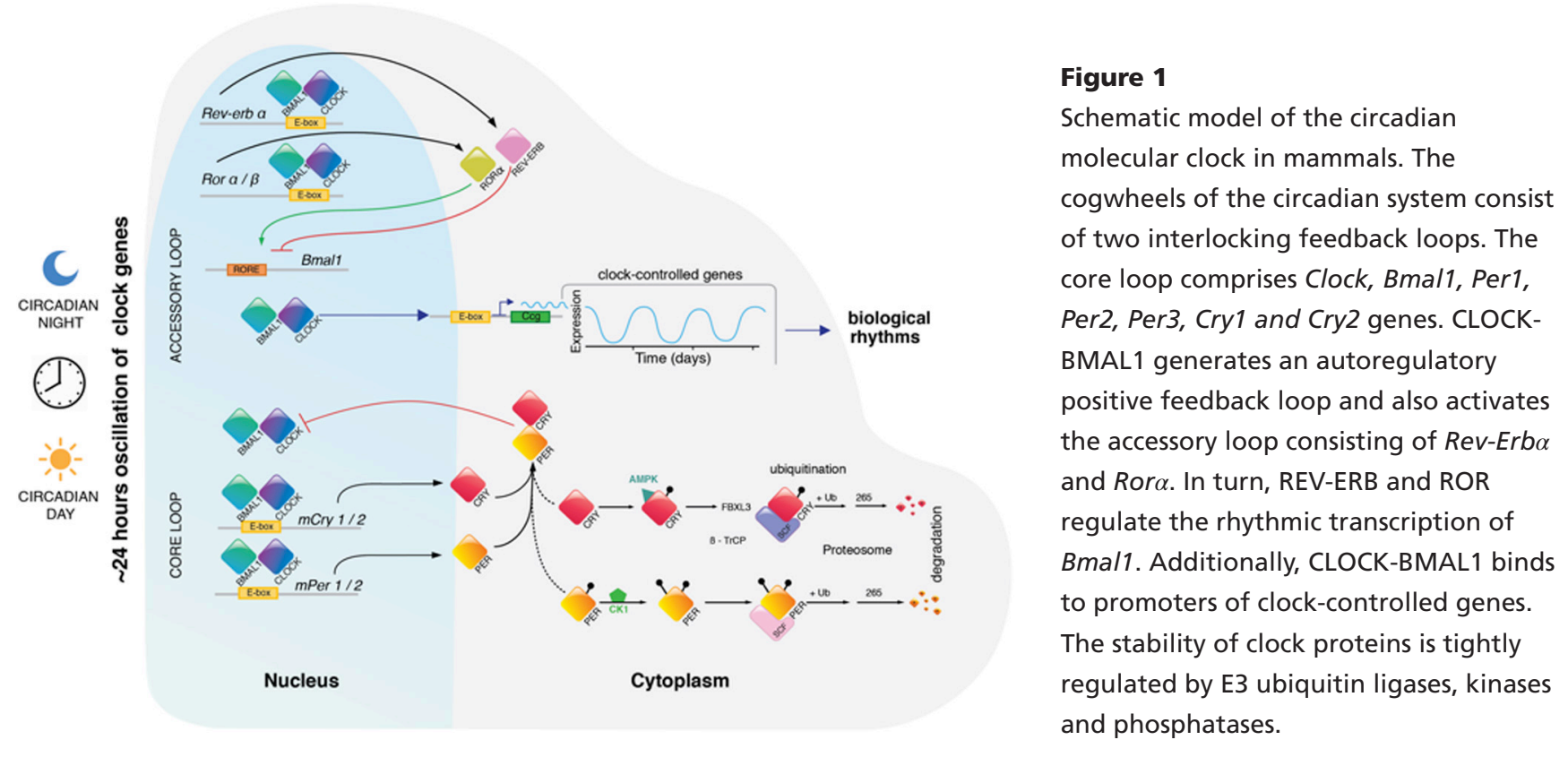

www.eje-online.org 
system depends on two main clock proteins, CLOCK and BMAL1, constituting heterodimeric transcriptional activators of a positive feedback loop. These heterodimers activate their target genes at E-boxes in promoters of core genes Per1, Per2, Per3, Cry1 and Cry2. These genes then interact with CLOCK-BMAL1, inhibiting their own transcription. CLOCK-BMAL1 also activates a second feedback loop that increases the mRNA levels of Rev-Erbo (Nr1d1) and Ror $\alpha$. In turn, REV-ERB and ROR proteins inhibit and activate the rhythmic transcription of Bmal1 respectively. The fine-tuning of the molecular circadian timekeeping system depends on photic and nonphotic environmental synchronisers, such as light-darkness cycles, food ingestion, temperature, rest/activity cycles and social cues $(26,27,28)$. Furthermore, light-darkness cycles seem to be a stronger zeitgeber than environmental temperature or food availability cycles, at least in mice (29). The primary action of the zeitgebers is to synchronise the clock system to a period of exactly $24 \mathrm{~h}$. Additionally, CLOCK, BMAL1 and CRY proteins bind to E-boxes within the promoters of more than a thousand target genes named clock-controlled or output genes $(30,31)$. Such genes are tissue specific and translate temporal information from clock genes to single cells and whole organs, thereby controlling physiological functions $(32,33)$.

\section{Circadian rhythm in the hypothalamic-pituitary-adrenal (HPA) axis}

The endogenous circadian rhythm in the HPA axis is one of the best-documented cyclic endocrine activities showing daily variations in plasma glucocorticoids: cortisol in humans and corticosterone in rats. Peak concentrations have been reported to occur prior to or at the time of activity onset, daytime in humans and night-time in nocturnal animals and decline over the remaining 24 -h period (27, $34,35)$. Moreover, molecular mechanisms controlling the HPA circadian rhythm have been widely studied in rodents and non-human primates. Plasma glucocorticoid variations depend on the expression of intrinsic clock genes in the anatomic components of the HPA axis, which are organised in a hierarchical manner $(36,37)$. Circadian timing signals are propagated downstream from the hypothalamic suprachiasmatic nucleus (SCN) clock genes to other hypothalamic nuclei, pineal gland, pituitary and adrenal clock genes by controlling cyclic hormonal factors and autonomic innervations. Figure 2 provides a schematic representation of the multi-oscillatory system of the HPA axis circadian rhythm in normal subjects.

\section{SCN regulation of the HPA axis circadian rhythm}

The mammalian SCN comprises paired bilateral structures of the ventral hypothalamus containing approximately 20000 and 100000 neurons in mice and humans respectively (38). Each unilateral SCN has two anatomic subdivisions: a ventral 'core' region, which touches the optic chiasm and receives retinal input, and a dorsal 'shell' region, which receives input from the core (39). Neurons in the core and shell subregions are distinguished by neurochemical phenotype and vary substantially across species. Vasoactive intestinal polypeptide (VIP), the most abundant neuropeptide in core neurons, is released rhythmically from the core and also strongly involved in SCN coupling. The core also contains calretinin, neurotensin and gastrin-releasing peptide. Shell neurons, on the other hand, contain predominately arginine vasopressin (AVP), angiotensin II and met-enkephalin. These neuropeptides are colocalised with gamma-aminobutyric acid (GABA) in most SCN neurons, while synapses among SCN neurons are mostly GABAergic (39). Cell-cell communication via chemical and electrical synapses may be the primary contributor to normal rhythmicity. Such network properties across the entire SCN provide rhythmic stability to the molecular circadian cogwheels. Although each neuron contains a cell-autonomous circadian oscillator, the SCN network contributes to the synchronisation of cellular oscillations and increases clock precision (39).

The neuroanatomy of the circadian rhythm system, which has been extensively reviewed by Morin (40), is considered complex. The mammalian SCN receives a bilateral input of luminance information via the retinohypothalamic tract (RHT) from photosensitive ganglion cells of the retina (ipRGCs). These cells express the photopigment melanopsin (Opn4), which is not involved in image formation but is essential for SCN light entrainment $(41,42)$. Moreover, Per1 and Per2 genes, which are co-expressed in SCN cells, are induced in response to external light unlike Per3 (43). This is ascribed to the fact of only Per1 and Per2 promoters contain CREs that bind to CRE-binding protein. This light signallingdependent activation of Per1 and Per2 gene expression is distinct from the CLOCK/BMAL1 feedback loop (43). Apart from the RHT, the SCN is also interconnected with many other regions of the brain, such as the median raphe serotonergic pathway, the geniculohypothalamic pathway and the NPY-containing pathway from the thalamic intergeniculate leaflet, which also contribute 


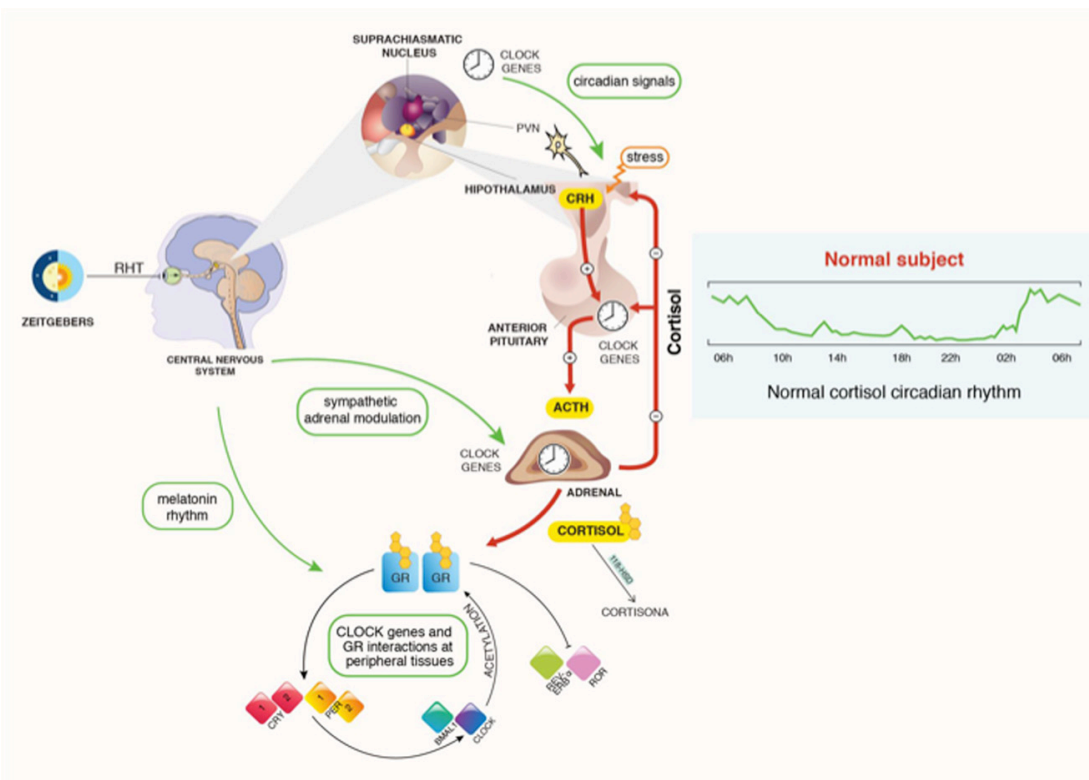

\section{Figure 2}

Circadian rhythm of the hypothalamicpituitary-adrenal axis in normal subjects: a multi-oscillatory system. Plasma glucocorticoid variation depends on the expression of intrinsic clock genes in the anatomic components of the HPA axis, which are organised in a hierarchical manner. Circadian timing signals are propagated downstream from the hypothalamic suprachiasmatic nucleus clock genes to other hypothalamic nuclei, pineal gland, pituitary gland and adrenal clock genes by controlling cyclic hormonal factors and autonomic innervations. AVP, arginine vasopressin; GR, glucocorticoid receptor; PVN, paraventricular nucleus; $\mathrm{RHT}$, retinohypothalamic tract. to circadian rhythm regulation (40). As conventionally accepted, light through the RHT entrains the SCN clock. In addition, recent studies suggest that light may also control peripheral clocks independent of the SCN clock. However, the nature of these additional pathways remains to be elucidated $(44,45)$.

The SCN output signals are mediated by circadian variation of neuronal firing and humoral output. Neuroanatomical tracing studies have demonstrated a non-uniform distribution of labelled cells across the SCN (46). These studies described three major patterns of SCN efferent projections in rats. The most robust pattern consists of input to the parvocellular portion of the paraventricular nucleus (PVN), periventricular hypothalamic nuclei, preoptic region, subparaventricular zone, dorsomedial nucleus (DMH), retrochiasmatic area and premammillary area (46). The parvocellular portion of the PVN contains neuroendocrine neurons that synthesise corticotrophinreleasing hormone (CRH), as well as AVP in almost half of these SCN neurons. Based on time of death, SCN neurons obtained during the autopsy of young human subjects showed a circadian rhythm among immunoreactive AVP neurons, which peaked during the early morning (47). Moreover, AVP mRNA diurnal variations in rat SCN revealed higher expressions in the morning (48). These data are consistent with those from transgenic rats expressing AVP-enhanced green fluorescent protein fusion gene, which allowed the detection of diurnal AVP mRNA changes in the dorsomedial SCN (49), corroborating the role of AVP as an important output neurotransmitter of the SCN. Notably, AVP is released by the SCN during the light period in both nocturnal and diurnal species. In nocturnal animals, AVP released during the light period inhibits CRH-containing neurons in the subPVN and $\mathrm{DMH}$ nuclei via GABAergic interneurons. In the diurnal species, however, AVP released during the light period stimulates CRH-containing neurons via glutamatergic interneurons in the same nuclei. The existence of different neurotransmitter pathways downstream of the SCN may explain the mechanism behind the 12-h reversal of certain rhythms, including HPA axis circadian activity, in both nocturnal and diurnal species (50).

In addition, endocrine circadian activity relies on a neural connection between the SCN and pineal gland. The SCN controls the circadian rhythm of melatonin synthesis in the mammalian pineal gland via multisynaptic pathways, including preautonomic neurons of the PVN, sympathetic preganglionic neurons in the spinal cord and noradrenergic neurons of the superior cervical ganglion (51). Melatonin blood levels display a circadian variation, with high concentrations during the night, in both diurnal and nocturnal animals, reflecting an internal darkness signal. Melatonin is also an important efferent pathway, distributing temporal cues from mammalian SCN to a large number of tissues expressing melatonin receptors, including the adrenal glands (52). Notably, evidence has shown that melatonin acts on the SCN, in turn directly influencing the circadian clock mechanism. Melatonin could inhibit proteasomal destruction of clock proteins, such as BMAIL and REV$\mathrm{ERB} \alpha$, and interfere with molecular feedback loops, particularly at night (53). 
CRH is the principal neurohumoral signal controlling adrenocorticotrophic hormone (ACTH) secretion and glucocorticoid rhythms $(54,55)$. CRH is mainly synthesised in the parvocellular and magnocellular neurons of the PVN. Approximately half of the CRH neurons co-express AVP, while their axons project to the median eminence, releasing CRH and AVP to stimulate ACTH release from the anterior pituitary gland (56), which in turn controls the release of glucocorticoids via its stimulatory action on the adrenal cortex $(57,58,59)$. Notably, continuous infusion of CRH in healthy males leads to a retention of circadian rhythmicity in ACTH secretion. Thus, other stimulatory factors, such as AVP, may possibly control the circadian rhythm of ACTH and cortisol (60).

Furthermore, evidence has indicated that SCN also regulates adrenal circadian activity independent of CRH-ACTH stimuli. Morphological data support the role of direct sympathetic innervation in modulating adrenal glucocorticoid secretion (61). In addition, physiological studies have shown a circadian rhythm in adrenal responsiveness to exogenous ACTH $(27,62)$. Notably, plasma corticosterone had a more pronounced (5- to 10-fold) circadian variation amplitude compared to plasma ACTH $(27,62)$. The hypothesis is that hypothalamic PVN neurons, which receive input from the SCN, project to the sympathetic preganglionic neurons in the spinal cord and provide inhibitory and excitatory inputs to the adrenal cortex, possibly via a cAMP-mediated pathway, thereby increasing free cholesterol transport into the mitochondria for steroidogenesis (63). Therefore, the circadian neuronal control of the adrenal glands amplifies the effects of plasma ACTH rhythmicity on driving the glucocorticoid circadian rhythm (60).

\section{Clock gene expression in the HPA axis}

Throughout the last decade, evidence has shown that each anatomic component of the HPA axis possesses a unique circadian expression of clock genes, leading to characteristic circadian signatures for each tissue. Rhythmic clock gene expression had been observed in the adrenal glands of the rhesus monkey and rodents. Like humans, rhesus monkeys are more active during the day. Furthermore, adrenal expression of Per1 and Per2 peaked at the beginning of the light phase and was synchronised with the peak of plasma cortisol (37). Conversely, mouse adrenal studies performed under similar photoperiodic conditions reported that Per1 and Per2 acrophases occurred closer to the darkness phase in synchrony with the peak of corticosterone (64). Majority of the canonical clock genes (Bmal1, Cry1, Per1, Per2, Per3 and $R e v-E r b \alpha$ ) exhibited a circadian expression pattern in both the glomerulosa and fasciculata zones of the mouse adrenal gland (65). However, Clock and Cry2 transcripts did not show an obvious circadian rhythm. Moreover, the circadian rhythmicity of the Per1, Per2 and Bmal1 genes in the rat adrenal gland remained unaltered after hypophysectomy, indicating that the activity of the adrenal oscillators was independent of SCN signalling via the pituitary gland (66). Additional focused analyses revealed that STAR mRNA and protein, a rate-limiting regulator of steroidogenesis, possessed circadian variation with a late-daytime acrophase in accordance with plasma corticosterone profiles in mice (67). Notably, STAR gene expression was transcriptionally regulated by the binding of CLOCK/BMAL1 heterodimers to Star upstream cis elements of the murine promoter, indicating a direct link between adrenocortical clock genes and the regulation of steroidogenesis (67). These studies indicated that the glucocorticoid circadian rhythm was also dependent on a well-organised level of rhythmicity within the adrenal cortex.

Girotti et al. (36) examined the 24-h pattern of ACTH and corticosterone secretion, the functional expression of c-fos, Crh, Pomc and Star and the expression of Per1, Per2 and Bmal clock genes in each component of the HPA axis. They subsequently compared hormone rhythms with circadian rhythms of clock genes in the adrenal gland, pituitary gland and SCN. Among adult rats fed ad libitum, the corticosterone rhythm acrophase occurred at the onset of the darkness period and was in phase with Star, Per1 and Per2 expression rhythms in the adrenal glands. Moreover, Bmal temporal expression was in antiphase with Per1 expression in the adrenal cortex and in phase with Bmal circadian expression in the anterior pituitary gland. Interestingly, diurnal rhythms in plasma ACTH and Pomc gene expression in the pituitary gland were not as evident as those in adrenal clock genes. However, Per2 and Bmal expressions in the anterior pituitary gland showed a clear rhythm and were in antiphase with each other. In the SCN, Per1 and Per 2 acrophases occurred during the light period, whereas Bmal peaks occurred during the darkness period (68). These genes also showed a clear rhythm in the PVN while being in antiphase with their respective expressions in the SCN. Moreover, Crh expression in the PVN displayed an evident circadian rhythm in phase with Bmal circadian expression (36).

Our group showed that among rats that had food access ad libitum and those that had restricted food 
access, different phases in clock genes expression were observed in the SCN, PVN and ARC. In addition, clock gene expression in the SCN, PVN and ARC responded to feeding schedules in a tissue-specific manner, despite on-going photoperiod zeitgeber (69). Recently, Chung et al. (70) demonstrated that in mice, adrenal clockdependent steroidogenesis and the SCN-driven central mechanism regulating corticosterone release cooperate to produce a daily rhythm in circulating glucocorticoids. Taken together, these studies demonstrate that each component of the HPA axis has a distinctive circadian clock gene expression, although the main timing signals are propagated downstream from the SCN to the HPA axis.

\section{Circulating glucocorticoids as a circadian signal}

Circulating glucocorticoids, the end-effectors of the HPA axis, regulate a broad spectrum of physiologic functions while also serving as a humoral signal that transduces circadian variation signals from the SCN pacemaker to reset peripheral clock gene expression $(71,72,59)$. Thus, glucocorticoids influence brain regions outside the SCN, such as the PVN, pineal gland, central amygdala, stria terminalis, hippocampus and pituitary gland (73), as well as peripheral tissues, such as the liver, gut, muscles, white adipose tissues, lungs, kidneys, bone, skin, blood, cardiovascular and immune/inflammatory systems (59). A recent study suggested that corticosteroid rhythmicity is necessary for maintaining high amplitude with no regulatory impact on clock gene phases in peripheral tissues (74).

At the cellular level, glucocorticoids exert their diverse effects via a specific intracellular receptor, the glucocorticoid receptor (GR), which belongs to the nuclear receptor superfamily and is expressed in almost all human tissues and organs $(75,76)$. In addition to genomic actions, GRs also exert rapid, non-genomic effects, which are possibly mediated by membrane-localised receptors or by translocation into the mitochondria. The molecular mechanisms of human GR action and variability in glucocorticoid sensitivity have already been reviewed elsewhere $(77,78)$. Additionally, clock genes and GR expression in peripheral tissues possess a reciprocal interaction. Daily variations in corticosteroids reset circadian rhythms of peripheral clock genes Per1, Per2, Bmal1, Cry1 and Cry2. Meanwhile, CLOCK-BMAL1 proteins modulate the activity and bioavailability of GRs through acetylation $(79,71)$. In addition, Lamia (80) showed that both circadian co-regulators, Cry1 and Cry2, interact with GRs in a ligand-dependent manner to oppose the transcriptional response to glucocorticoids. The crosstalk between clock genes and GRs provides a finely tuned molecular feedback loop that modulates the effects of glucocorticoid circadian rhythm in peripheral tissues. Furthermore, the relative activities of both type 1 and type $211-\beta$-hydroxysteroid dehydrogenase isoenzymes, which interconvert inactive cortisone into active cortisol, or vice-versa, play an important role in the regulation of tissue cortisol concentrations (81).

Glucocorticoids have also been well known to suppress CRH secretion in the PVN and ACTH secretion in the anterior pituitary gland, establishing a negative feedback loop that resets the activated HPA axis. Glucocorticoids exert rapid negative feedback mediated by GRs in CRH neurons and pituitary corticotrophs through rapid steroid action in the PVN involving the glucocorticoidendocannabinoid interface via activation of the G-proteindependent signalling pathway (82). The delayed effects include the inhibition of pro-opiomelanocortin (POMC) and $\mathrm{CRH}$ transcription due to mRNA and protein turnover (83). Thus, besides the classical neuroendocrine regulation of the HPA axis, synchronisation can be observed among clock genes in each anatomic component of the HPA axis via feedback loops involving clock genes, proteins and corticosteroids. These reciprocal interactions between molecular and physiological oscillations at multiple levels of the HPA axis result in a robust circadian rhythm of plasma glucocorticoids.

\section{The ontogeny of the glucocorticoid circadian rhythm}

The development of the glucocorticoid circadian rhythm follows the gradual maturation of the SCN and HPA axis. Although the ontogeny of the SCN and circadian rhythms in foetal and neonatal rats, hamsters and sheep has been extensively described $(84,85,86,87)$, scanty data are available for primates $(87,88)$, primarily humans $(89,90)$. Human foetal SCN neurogenesis is almost completed between the 18th and 30th week of gestation. Moreover, the PVN is already formed at the 25th week of gestation (89), while RHT maturation takes place at the end of gestation. Accordingly, evaluation of the daily ${ }^{14} \mathrm{C}$-labelled deoxyglucose utilisation patterns in squirrel monkey foetuses during late foetal development confirmed that the SCN was metabolically more active in the morning than at night (91). In addition, light induced 
a robust increase in SCN metabolic activity and Per1 gene expression in baboon infants at ages equivalent to 24 weeks after conception in humans (92). Furthermore, circadian rhythms of several physiological functions, such as heart rate and foetal movements, are present in human foetuses at a gestational age of 29-35 weeks (93). These data provide evidence that the primate SCN circadian clock is already functioning and responsive to light prenatally, while the rat SCN develops gradually with neurogenesis being completed only after birth $(84,85,86$, 87). In addition, ipRGC projection to the $S C N$ via the RHT and maturation of light signalling are completed around P10 in rats, while circadian rhythms of temperature, locomotor activity, drinking and plasma corticosterone also develop after birth $(84,86,94)$.

Molecular studies have supported evidence regarding the presence of circadian rhythmicity in SCN clock genes during foetal and neonatal periods in mammals $(95,96$, 97). During the foetal stage, in situ hybridisation found no detectable Per1, Per2, Cry1 and Bmal1 gene rhythms in the rat SCN at E19, whereas a clear oscillation was observed from P3 to P10 and thereafter $(95,96)$. A study utilising foetal rat SCN sampling via laser microdissection confirmed the absence of Per2 and Bmal1 rhythms at E19, whereas rhythmic expressions of Rev-Erb $\alpha$ and other genes related to cellular activity (c-fos, Avp and Vip) were observed. However, Per2 and Bmal1 expressions exhibited low amplitude but significant rhythmicity at E21 (98). These studies suggested that the development of clock gene rhythms in the foetal SCN could, theoretically, be entrained by Rev-Erb $\alpha$ oscillations driven by maternal cues rather than the foetal circadian system (98). Another review on the circadian cogwheel development of the non-primate $\mathrm{SCN}$ demonstrated that genes in the negative feedback loop of the core clock become rhythmic earlier than those in the positive feedback loop (99). Unlike that observed in the foetal rat SCN, robust oscillatory expressions of Bmal-1, Per-2, Cry-2 and Clock in the SCN and adrenal glands, as well as a circadian rhythm of plasma DHEAS, were observed among capuchin monkey foetuses at the end of gestation (100).

The establishment of the HPA axis circadian rhythm in neonatal rats, with a vespertine plasma corticosterone acrophase, has been determined to vary across different studies. Accordingly, such an event had been found to occur on postnatal days P30, P22, P21 or P16 (11, 12, 101, 102). Applying appropriate protocols and using cosinor-based rhythmometry, we had recently conducted a refined study on the emergence of rat postnatal corticosterone rhythm and its relationship with the adrenal rhythmicity of Clock, Bmal1, Per1, Per2, Per3, Cry1, Cry2 and Ror $\alpha /$ Rev-Erbo genes and steroidogenesis-related genes (Star and Mc2r) in rats from the early postnatal period until adulthood (103). In our study, rat pups at postnatal ages P1, P3, P6, P12, P14, P16, P21 and P24 were decapitated at 4-h intervals over a 24-h period. Accordingly, plasma corticosterone circadian rhythm with a morning acrophase (between ZT0 and ZT2, corresponding to 07:00-11:00 h) had been observed from P1 until P12 (Fig. 3). Plasma corticosterone rhythmicity, as well as a morning acrophase, at very early postnatal ages had never been previously described. This novel finding was subsequently ascribed to the time of breastfeeding. Conversely, a nocturnal acrophase had been observed at P14, P16, P21 and P24. In our experiments, this rhythm, which was well known in adult rats, had been associated with eye opening in pups at P14. We also demonstrated
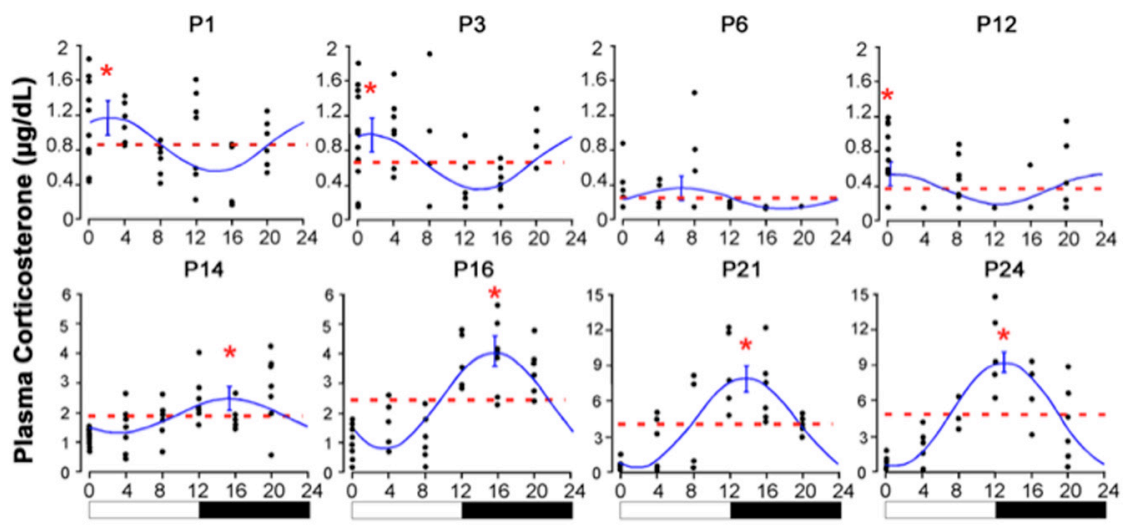

Zeitgeber time

\section{Figure 3}

Postnatal ontogeny of circadian plasma corticosterone in rats. Plasma

corticosterone concentrations at zeitgeber time $0,4,8,12,16$ and 20 on postnatal days P1 to P24. Dotted line: mesor; solid line: cosine curve and $95 \%$ confidence interval of the acrophase. *Differences between peak and mesor concentrations. Black bars represent the dark phase (Reproduced with permission from: Postnatal Ontogeny of the Circadian Expression of the Adrenal Clock Genes and Corticosterone Rhythm in Male Rats. Endocrinology. 2017; 158(5):1339-1346). 
circadian variations, as well as a morning acrophase, in the mRNA expression of Bmal1, Per2, Per3 and Cry 1 genes from P3, whereas Rev-Erbo presented a nocturnal acrophase. From P14, Bmal1, Per2, Per3 and Cry1 acrophases advanced by approximately $10 \mathrm{~h}$ compared to early neonatal periods and became vespertine nocturnal (103), which was consistent with the adult circadian profile as previously described for adult rat adrenal glands (36).

The relationship between plasma corticosterone and clock gene acrophases in adrenal tissues was observed across all postnatal developmental ages. Accordingly, Per2 and $C r y 1$ circadian profiles were in phase with the circadian rhythm of plasma corticosterone, whereas Bmal1 was in antiphase (Fig. 4). Considering that rat SCN maturation and clock gene expression rhythmicity are completed only after P10 (86), we hypothesised that the external rhythmic cues for pups before P10 may have been derived from the maternal environment, entraining the circadian rhythm of adrenal clock genes and corticosterone secretion (103). Although adult rat activity is predominantly nocturnal, mothers approach the litter to feed their pups during the

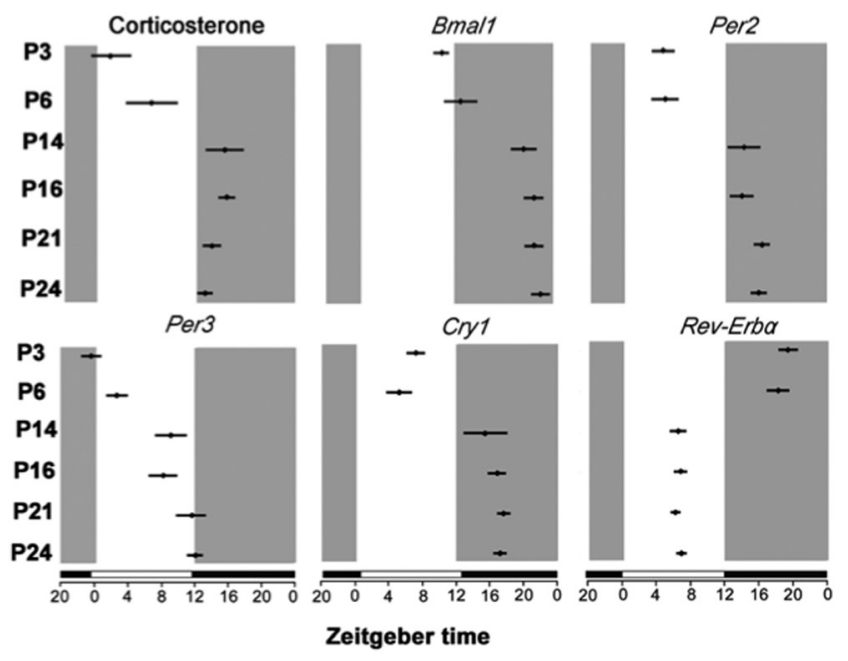

\section{Figure 4}

Acrophases of plasma corticosterone and clock gene expression during postnatal development in rats. Circles indicate the acrophase and $95 \%$ confidence interval of Bmal1, Per2, Per3, Cry1 and Rev-Erbo expressions and plasma corticosterone concentrations at zeitgeber time 0, 4, 8, 12, 16 and 20 on the postnatal days P1 to P24. Black bars represent the dark phase (Reproduced with permission from: Postnatal Ontogeny of the Circadian Expression of the Adrenal Clock Genes and Corticosterone Rhythm in Male Rats. Endocrinology. 2017; 1581339-1346). light phase. The mother's body temperature and tactile stimulation during breastfeeding (104), as well as high milk melatonin levels during night-time (105), may be identified as synchroniser agents. Furthermore, melatonin may synchronise Per2, Bmal1 and StAR expression phases in rat foetal adrenal glands in parallel with decreasing corticosterone levels $(106,107)$. In capuchin monkeys, however, maternal melatonin seems to be a zeitgeber for Bmal1 and Per 2 expression in the foetal SCN but not in the foetal adrenal glands (100). During the late postnatal phase, the entrainment of rat adrenal circadian variations may shift from maternal and nonphotic to photic cues. In addition to light, daily patterns of food ingestion and motor activity can also act as synchroniser agents in adult rats. Taken together, these data suggest that rats exhibit a progressive postnatal maturation of circadian variations in adrenal clock genes, which is in synchrony with the development of the plasma corticosterone circadian rhythm (103).

Studies in various species have addressed the ontogeny of the postnatal glucocorticoid rhythm and its relationship with circadian expression of clock genes in different components of the HPA axis $(87,108,103)$. However, no studies regarding clock gene rhythmicity and its relationship with the ontogeny of the cortisol circadian rhythm have been conducted on human foetal tissues, such as the brain, pituitary gland or adrenal gland. The presence of a 24-h rhythm in umbilical artery plasma cortisol concentrations was demonstrated in human foetuses at term (109), suggesting that the human SCN and adrenal circadian clock systems function prenatally. Another study showed that 2 out of 10 healthy term neonates displayed a cortisol rhythm, which was not coupled to exogenous day/night cycles (110). However, no circadian rhythmicity in cortisol and $17 \alpha$-hydroxyprogesterone had been observed in saliva samples from 119 healthy neonates collected $18-24 \mathrm{~h}$ or $25-55 \mathrm{~h}$ after birth (111). These data suggest that circadian cortisol secretion may increase later in gestation and may not uniformly occur in all infants of the same age. In addition, given that birth seems to induce re-entrainment, circadian cortisol secretion may be present at birth, despite synchronisation to day/night cycles taking place after the neonatal period (112). Although the aforementioned studies involved human samples collected during the first few hours after birth, the question regarding the onset of the early morning glucocorticoid peak and its maintenance in subsequent postnatal weeks remains unsolved.

Previous data have described the emergence of the plasma cortisol circadian rhythm in children aged between 
1 and 3 years (13), 6 months (14) and between the second and third month of life $(113,114)$. Discrepancies in human studies regarding the age wherein plasma cortisol circadian variations appear could be ascribed to the ethical difficulties in obtaining serial blood samples from infants. This limitation had been overcome during the last decades with salivary cortisol measurements, an index of plasma free cortisol that has been used as a tool in longitudinal protocols, given that saliva samples are easier to collect at home many times a day over consecutive days and obtained via a non-invasive procedure that causes no pain or stress for the infant $(115,34)$.

Four previous longitudinal studies that used salivary cortisol from healthy term infants found that the mean age wherein adult-like rhythm became apparent was between the first and third month of life $(116,117,118,119)$.

All aforementioned studies performed saliva sampling many times a day, including morning, afternoon and night, started collection from 2 weeks until 12 months after birth and had a varying number of healthy term infants. The observed divergences could have been due to the different mathematical definitions of circadian rhythms. One definition of circadian rhythmicity was the amplitude between morning and evening values with a steady decline throughout the day (116). Other definitions of circadian rhythmicity were assumed when night values were less than three times the mean intraassay variation from the morning value taken as $100 \%$ (117), when the median morning cortisol level was significantly higher than the median evening cortisol level (119) or when different methods were compared using multilevel analysis calculations (118). Altogether, these data confirm that salivary cortisol circadian rhythm appears in healthy term infants at least 1 month postnatal, which was earlier than previously thought. In addition, variability had been observed among healthy individuals (117). Indeed, approximately $30 \%$ of normal infants presented a circadian cortisol rhythm as earlier as 2 or 4 weeks postnatal.

Nevertheless, the correlation between plasma and salivary cortisol in preterm infants remains controversial $(120,121)$. Accordingly, our group was able to observe a correlation between plasma and salivary cortisol levels (120) while also showing the appearance of a salivary cortisol circadian rhythm in preterm infants at a median age of 8 postnatal weeks, similar to term infants. However, individual circadian rhythm in term and preterm infants emerged 2-16 weeks postnatal (122). It is important to point out that daily cortisol variations in our studies should have been maintained for consecutive weeks in order to be considered an established rhythm. More recently, Ivars et al. (123) described the development of a cortisol circadian rhythm in preterm infants on a group level at a corrected age of 1 month. However, they did not specify whether the rhythm had been maintained, as we did in our protocol. We also observed a similar age of salivary cortisol rhythm emergence in monozygotic and dizygotic twin pairs at 7.8 and 7.4 weeks, respectively (124). The heritability index and intraclass correlation coefficients suggest a greater environmental rather than genetic influence, indicating synchrony in the emergence of a cortisol circadian rhythm between each twin pair. This was likely to occur given that the twins shared prenatal and postnatal environmental synchronisers.

Ivars et al. found no correlation between the development of salivary cortisol rhythm and behavioural regularity (123). Our study, however, observed a parallelism between the appearance of a salivary cortisol rhythm and the onset of sleep rhythm (122) (Fig. 5). In addition, another study demonstrated a negative correlation between napping and cortisol levels only among older children (125). Taken together, all these data confirm circadian maturation of the HPA axis at a very early stage in human development. Moreover, the association between cortisol circadian rhythm and behavioural development, including sleep patterns, suggest that the complex neuroanatomical pathways, the clock gene system and the HPA axis become fully developed between 31 and 34 weeks post conception and continue to mature thereafter.

\section{Cortisol circadian variation in Cushing's disease}

Normal human adult cortisol secretion follows a diurnal variation with plasma levels peaking shortly after morning awakening, termed cortisol awakening response (CAR) (126), and decreasing thereafter, reaching a nadir around midnight. This pattern is maintained by changes in the amplitude of ACTH secretion throughout the day, leading to a mean of approximately 10 cortisol secretory peaks over $24 \mathrm{~h}(127,128,129)$. The oscillatory pattern had been well described using a waveform-independent deconvolution technique. Analysis of 24-h plasma concentration profiles in healthy subjects revealed that the nyctohemeral pattern of cortisol secretion can be accounted for by an amplitude-modulated, random burstlike mode of cortisol secretion without the need for postulating a tonic mode of cortisol release (130). This 

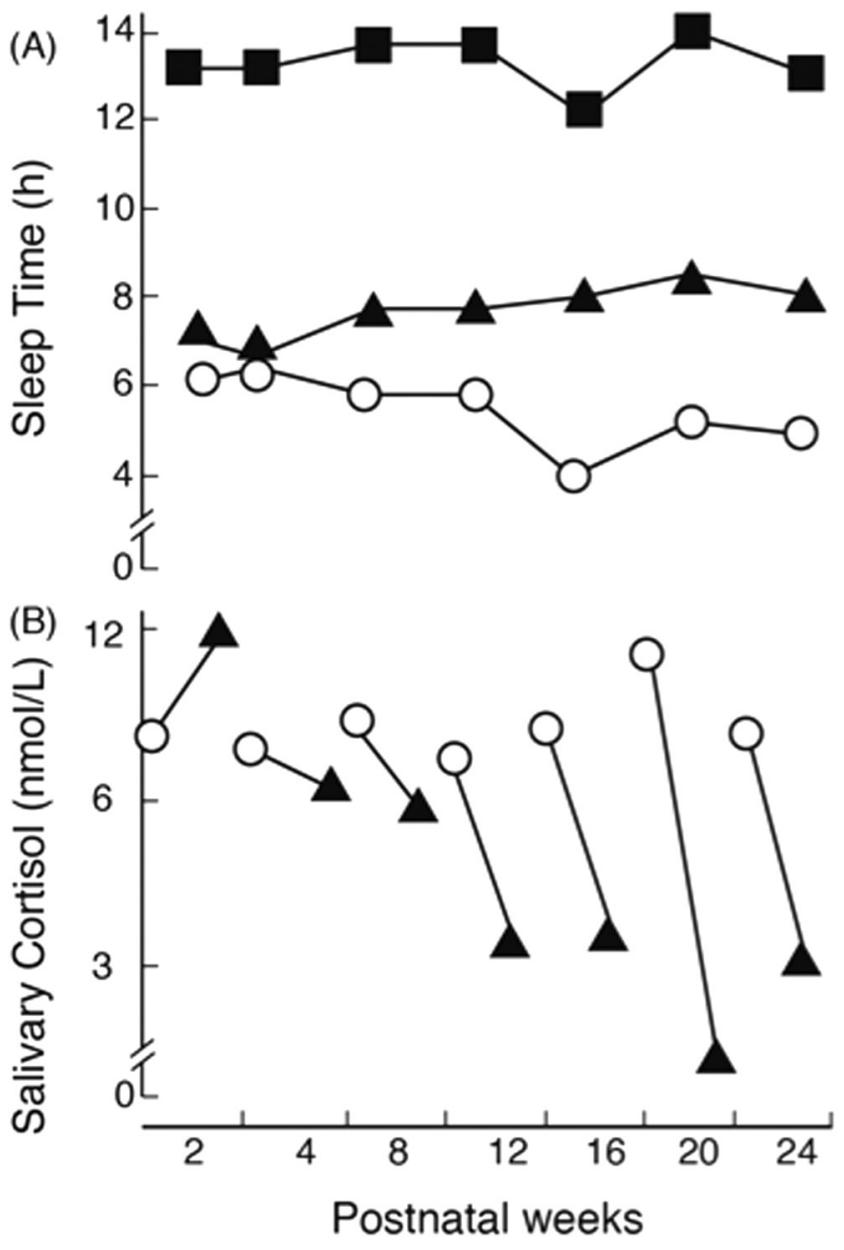

Figure 5

Ontogeny of salivary cortisol circadian rhythm and sleep activity in preterm infants. (A) Mean values of total 24-h sleep time (solid squares), nocturnal sleep time (solid triangles) and diurnal sleep time (open circles). (B) Mean concentration of salivary cortisol in the morning (open circles) and at night (solid triangles) (Adapted with permission from: The emergence of salivary cortisol circadian rhythm and its relationship to sleep activity in preterm infants. Clinical Endocrinology 2000 52:423-426).

dynamic concept regarding the physiological mode of cortisol secretion integrates random cortisol pulses with rhythmic circadian variations, eliminating the idea of a tonic glucocorticoid secretion mode (130). Aside from the ACTH-specific amplitude and/or frequency that control secretory burst activity, circadian ACTH and plasma cortisol concentrations in humans probably also depend on the expression of intrinsic clock genes in the HPA axis that oscillate at a periodicity of approximately $24 \mathrm{~h}$, as observed in rodents and non-primate mammals $(20,21$, 22). Abnormalities in the HPA axis circadian rhythm were observed in mice carrying mutated clock genes. Indeed, Per1- and Per2-null mice showed elevated corticosterone levels with no circadian rhythm (131), whereas Per1 $1^{\text {Brd }}$ mice demonstrated elevated glucocorticoid levels with no daily fluctuation. In addition, Per $1^{\text {Brd }}$ mice were smaller than wild-type mice and showed normal glucose tolerance and no apparent Cushingoid phenotype (132). To the best of our knowledge, no molecular studies on clock genes in Cushing's disease (pituitary ACTH-dependent Cushing's syndrome) have been conducted to date.

Simultaneous with the detailed characterisation of the normal circadian ACTH and cortisol secretion in healthy subjects, abnormalities in the HPA axis were described in patients with Cushing's disease. Accordingly, increased mean pulsatile ACTH amplitude but not frequency had been observed in patients with Cushing's disease (129, 133). This disruption led to the absence of the normal 24-h cortisol secretory variation and the failure of plasma cortisol levels to drop at late evening $(127,134)$. In addition to these alterations, another remarkable characteristic of corticotropinomas includes the partial resistance to the glucocorticoid inhibitory feedback. This feature is demonstrated by the failure of low-dose dexamethasone to dose-dependently suppress circulating cortisol or its urinary metabolites during a suppression test $(135,136)$.

Thus far, investigations on the structure and expression of CRH, AVP, ACTH and GR genes have not shown significant abnormalities that could explain the relative glucocorticoid resistance observed in corticotropinomas $(137,138,139)$. The loss of cortisol circadian rhythm is a hallmark of patients with Cushing's syndrome of adrenal or ectopic ACTH origin. However, some patients with Cushing's disease may exhibit cortisol circadian variation (140, 141, 142). Indeed, 57\% of patients with Cushing's disease completely lost salivary cortisol circadian rhythm, while $43 \%$ exhibited persistent diurnal variation albeit with abnormally high cortisol levels (143). HPA activity reflects the circadian release of hypothalamic CRH, which is difficult to measure in plasma and even in the inferior petrosal sinuses (144). Thus, as a substitute for portal vein $\mathrm{CRH}$, published studies have adopted cerebrospinal fluid CRH levels, which was described to have an evening acrophase and an early morning nadir in healthy volunteers (145), similar to the pattern described in rhesus monkeys (146). Notably, the CRH circadian pattern is in opposition to the circadian pattern observed for plasma or cerebrospinal fluid cortisol. On the other hand, patients with Cushing's disease exhibited lower levels of cerebrospinal fluid CRH compared to normal subjects, which returned to normal after pituitary adenomectomy 
$(147,148)$. CRH levels in the cerebrospinal fluid were also reduced in patients receiving steroid treatment (148) and dogs with hyperadrenocorticism due to an adrenocortical tumour (149). These data suggest that hypercortisolism causes reduced CRH concentrations.

Based on the aforementioned data, we hypothesised that patients with Cushing's syndrome lose their cortisol circadian rhythm once circadian CRH release in the portal vein is completely abolished. On the other hand, a number of patients with Cushing's disease exhibit only reduced $\mathrm{CRH}$ secretion. In such cases, ACTH secretion from the adenoma would be still under the relative control of the SCN circadian clock genes, which would explain the maintenance of the cortisol circadian rhythm in such patients even with abnormally high cortisol levels. However, the potential role of circadian inputs from sympathetic adrenal modulations, as well as the influence of the melatonin rhythm, cannot be ruled out. Indeed, the melatonin circadian rhythm is maintained in majority of the patients with Cushing's syndrome (150). Thus, in corticotropinomas, the glucocorticoid resistance in corticotrophs and the disrupted glucocorticoid circadian rhythm contribute to hypercortisolism and the dysregulation of the clock system in peripheral tissues, leading to intermediary metabolism alterations and clinical features of Cushing's disease (Fig. 6).

Biochemical strategies to establish a diagnosis of Cushing's syndrome have been based on measurements of urinary free cortisol (UFC), low-dose dexamethasone suppression tests (1 $\mathrm{mg}$ overnight or longer) and latenight salivary cortisol (LNSC) levels (151, 152, 153).
As will be focused in the present review, the use of LNSC measurements, a simple test that evaluates the presence or absence of cortisol circadian rhythm, in the screening of Cushing's syndrome has increased over time (154).

The importance of salivary steroid analysis for the evaluation of pituitary-adrenal function had been established during the late 1970s (155). However, not until the mid-1980s had its use for diagnosing Cushing's syndrome been suggested $(156,157)$. Subsequently, two studies clearly showed that salivary cortisol was a highly suitable screening procedure for determining patients with Cushing's syndrome $(158,143)$. A comparison between normal volunteers, obese patients and patients with Cushing's syndrome revealed a substantial overlap in morning salivary cortisol levels such that patients with Cushing's syndrome exhibited higher cortisol levels that were almost entirely outside the normal range at 23:00 h. This difference resulted in a sensitivity and specificity of $93.3 \%$ for the diagnosis of Cushing's syndrome (143). Indeed, several studies have confirmed that elevated LNSC levels are an excellent substitute for increased midnight serum cortisol levels in the diagnosis of Cushing's syndrome in adults (143, 157, 158, 159, $160,161,162)$ and children $(163,164)$. These data have been confirmed using meta-analysis $(165,166)$. Another strategy to improve the diagnostic accuracy of Cushing's syndrome is the substitution of plasma for salivary cortisol measurement after a $1 \mathrm{mg}$ dexamethasone suppression test $(156,157)$. Based on previous studies, the combination of saliva collection at 23:00 $\mathrm{h}$ and after $1 \mathrm{mg}$ dexamethasone overnight improved the diagnostic accuracy of Cushing's

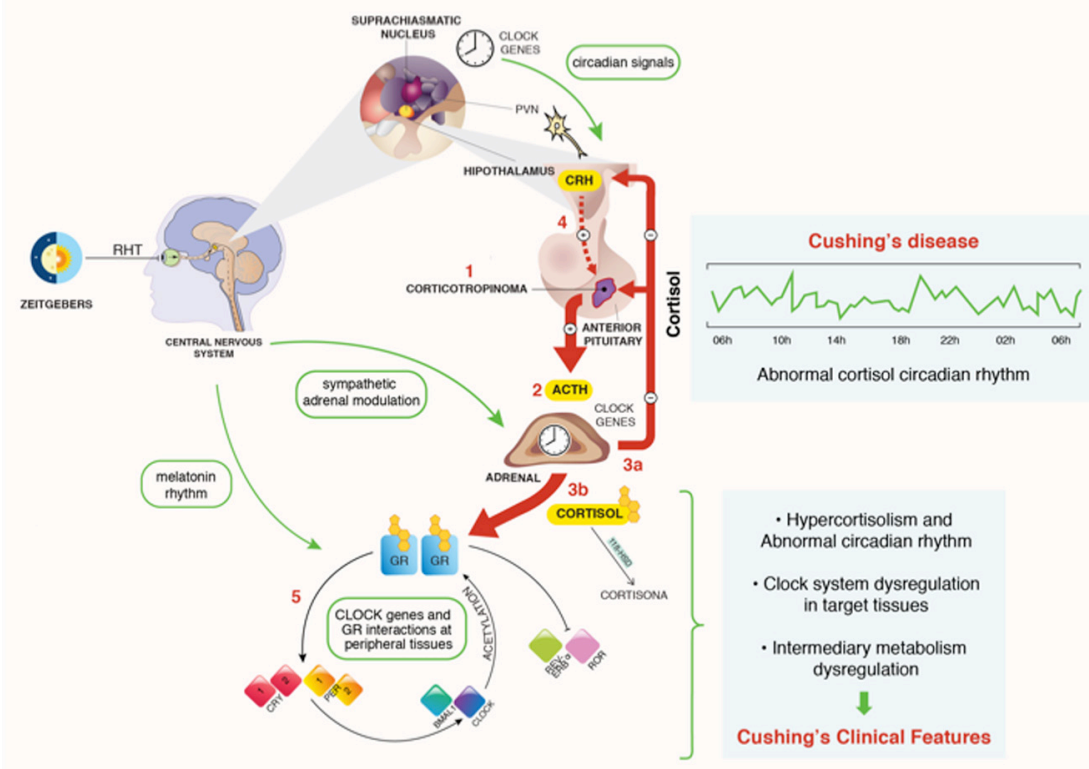

Figure 6

Abnormal cortisol circadian rhythm and dysregulation of clock genes in the physiopathology of Cushing's disease. Corticotropinomas are partially resistant to cortisol negative feedback (1), leading to increased ACTH secretion (2). In turn, increased cortisol (3a) reduces $\mathrm{CRH}$ concentrations (4) and leads to abnormal cortisol rhythm. Disrupted glucocorticoid circadian rhythm and hypercortisolism (3b) deregulate the interaction between the glucocorticoid receptor (GR) and clock system in peripheral tissues (5). PVN, paraventricular nucleus; RHT: retinohypothalamic tract. 
syndrome in adults and children $(143,163)$. It is important to highlight that salivary cortisol diagnostic cut-offs and diagnostic performance vary between reports because of the different assays used $(151,165,167)$.

In a more recent prospective study (168), we compared the variability, reproducibility and diagnostic performances of LNSC and UFC using simultaneous samples of 43 patients with Cushing's disease for 3 consecutive days. UFC failed to diagnose $18.6 \%$ of patients with Cushing's disease, whereas LNSC failed in only $2.3 \%$ (Fig. 7). The receiver-operating characteristic curves confirmed that LNSC was better in diagnosing Cushing's disease than UFC. The superiority of LNSC over UFC for diagnosing either current or early-stage recurrence of Cushing's syndrome had been observed despite high variability for LNSC $(168,169)$. Considering the variability, at least three LNSC sampling is recommended. Altogether, these data
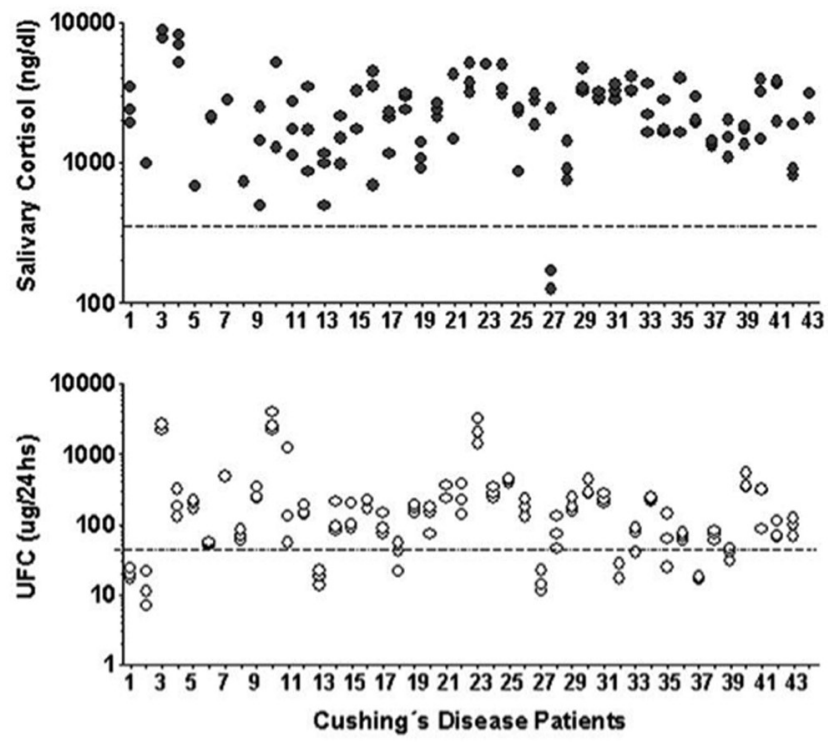

\section{Figure 7}

Diagnostic performance of late-night salivary cortisol and urinary free cortisol in Cushing's disease. Individual values of three concurrent and consecutive late-night salivary cortisol (LNSC) and urinary free cortisol (UFC) samples obtained from 43 patients with Cushing's disease (CD). The dotted line represents the cut-off values for LNSC ( $350 \mathrm{ng} / \mathrm{dL})$ and UFC $(43 \mu \mathrm{g} / 24 \mathrm{~h})$. UFC failed to diagnose $18.6 \%$ of patients with Cushing's disease, whereas LNSC failed in only $2.3 \%$, confirming the superiority of LNSC. (Reproduced with permission from: Late-night Salivary Cortisol Has a Better Performance than Urinary Free Cortisol in the Diagnosis of Cushing's Syndrome. Journal of Clinical Endocrinology \& Metabolism 2014; 99 2045-2051. indicate that loss of salivary cortisol circadian rhythm is an early marker for Cushing's disease, while increased UFC seems to occur later during the natural progression of the disease $(168,169)$.

Moreover, a distinct phenomenon termed CAR appears to be superimposing the circadian rhythm of cortisol $(170,171)$. CAR is the rapid increase in cortisol levels within 30-45 min after morning awakening. We showed blunted CAR in patients with active Cushing's disease, which can be related to hypercortisolism upon awakening. This subtle dysfunction of the HPA axis may represent a distinct and additional physiopathological phenomenon overlaying the disrupted cortisol circadian rhythm in patients with Cushing's disease (172).

\section{Concluding remarks}

The feedback loops between clock genes and their transcript proteins determine a self-sustained circadian rhythm with a periodicity of approximately $24 \mathrm{~h}$. Moreover, the fine-tuning of the molecular circadian timekeeping system depends on photic and nonphotic environmental synchronisers. Clock genes and their transcript proteins bind to the promoters of more than a thousand clock-controlled target genes. The endogenous circadian rhythm of the HPA axis is propagated downstream from the SCN to other hypothalamic nuclei, pituitary and adrenal circadian clock genes by controlling cyclic hormonal factors and autonomic innervations. Circulating glucocorticoids, which are the end-effectors of the HPA axis, regulate physiologic function while also serving as a transducer of circadian signals from the SCN pacemaker to reset peripheral clock genes, which in turn interact reciprocally with GRs. These interactions between molecular and physiological oscillations result in the plasma glucocorticoid circadian rhythm, the development of which follows the gradual maturation of the SCN and HPA axis. The SCN circadian clock in primates is already functioning and responsive to light prenatally, while salivary cortisol circadian rhythm in infants becomes apparent at around 1 month postnatal. In corticotropinomas, the glucocorticoid resistance in corticotrophs and the disrupted cortisol circadian rhythm contribute to hypercortisolism and clock system dysregulation in target tissues, leading to alterations in intermediary metabolism and clinical features of Cushing's disease. For diagnostic purposes, an abnormal salivary cortisol circadian rhythm seems to be an early marker of Cushing's disease. 


\section{Declaration of interest}

The authors declare that there is no conflict of interest that could be perceived as prejudicing the impartiality of this review.

\section{Funding}

Sao Paulo State Research Foundation (FAPESP), grant \#2013/09799-1 to A C M and grant \#2014/03989-6 to S R A and M C.

\section{Acknowledgement}

This article is dedicated to Prof. José Antunes-Rodrigues and Prof. Dorothy T. Krieger.

\section{References}

1 Aschoff J. Circadian rhythms: general features and endocrinological aspects. In Endocrine Rhythms, Comprehens, pp 1-61. Ed DT Krieger. New York, NY: Raven Press, 1979.

2 Gamble KL, Berry R, Frank SJ \& Young M. Circadian clock control of endocrine factors. Nature Reviews Endocrinology 201410 466-475. (https://doi.org/10.1038/nrendo.2014.78.)

3 Pincus G. A diurnal rhythm in the secretion of urinary 17-ketosteroids in young men. Journal of Clinical Endocrinology and Metabolism 19433 195-199. (https://doi.org/10.1210/jcem-3-4-195)

4 Guillemin R, Dear WE \& Liebelt RA. Nychthemeral variations in plasma free corticosteroid levels of the rat. Proceedings of the Society for Experimental Biology and Medicine 1959101 394-395. (https://doi. org/10.3181/00379727-101-24955)

5 Bliss EL, Sandberg AA, Nelson DH \& Eik-Nes K. The normal levels of 17-hydroxycorticosteroids in the peripheral blood of man. Journal of Clinical Investigation 195332 818-823. (https://doi.org/10.1172/ JCI102798)

6 Laidlaw JC, Reddy WJ, Jenkins D, Haydar NA, Renold AE \& Thorn GW. Advances in the diagnosis of altered states of adrenocortical function. New England Journal of Medicine 1955253 747-753. (https://doi.org/10.1056/NEJM195511032531801)

7 Doe RP, Vennes JA \& Flink EB. Diurnal variation of 17-hydroxycorticosteroids, sodium, potassium, magnesium and creatinine in normal subjects and in cases of treated adrenal insufficiency and Cushing's syndrome. Journal of Clinical Endocrinology and Metabolism 196020 253-265. (https://doi. org/10.1210/jcem-20-2-253)

8 Halberg F. Physiologic 24-hour periodicity; general and procedural considerations with reference to the adrenal cycle. Internationale Zeitschrift Fur Vitaminforschung Beiheft 195910 225-296.

9 Halberg F. Chronobiology. Annual Review of Physiology 196931 675-726. (https://doi.org/10.1146/annurev.ph.31.030169.003331)

10 Cornelissen G. Cosinor-based rhythmometry. Theoretical Biology and Medical Modelling 201411 1-24. (https://doi.org/10.1186/1742-468211-16)

11 Allen C \& Kendall JW. Maturation of the circadian rhythm of plasma corticosterone in the rat. Endocrinology 196780 926-930. (https:// doi.org/10.1210/endo-80-5-926)

12 Levin R \& Levine S. Development of circadian periodicity in base and stress levels of corticosterone. American Journal of Physiology 1975229 1397-1399. (https://doi.org/10.1152/ ajplegacy.1975.229.5.1397)

13 Franks RC. Diurnal variation of plasma 17-hydroxycorticosteroids in children. Journal of Clinical Endocrinology and Metabolism 196727 75-78. (https://doi.org/10.1210/jcem-27-1-75)

14 Onishi S, Miyazawa G, Nishimura Y, Sugiyama S, Yamakawa T, Inagaki $\mathrm{H}$, Katoh T, Itoh $\mathrm{S} \&$ Isobe K. Postnatal development of circadian rhythm in serum cortisol levels in children. Pediatrics 1983 72 399-404.

15 Konopka RJ \& Benzer S. Clock mutants of Drosophila melanogaster. PNAS 197168 2112-2116. (https://doi.org/10.1073/pnas.68.9.2112)

16 Bargiello TA \& Young MW. Molecular genetics of a biological clock in Drosophila. PNAS 198481 2142-2146. (https://doi.org/10.1073/ pnas.81.7.2142)

17 Reddy P, Zehring WA, Wheeler DA, Pirrotta V, Hadfield C, Hall JC \& Rosbash M. Molecular analysis of the period locus in Drosophila melanogaster and identification of a transcript involved in biological rhythms. Cell 198438 701-710. (https://doi.org/10.1016/00928674(84)90265-4)

18 Hardin PE, Hall JC \& Rosbash M. Feedback of the Drosophila period gene product on circadian cycling of its messenger RNA levels. Nature 1990343 536-540. (https://doi.org/10.1038/343536a0)

19 Vitaterna MH, King DP, Chang AM, Kornhauser JM, Lowrey PL, McDonald JD, Dove WF, Pinto LH, Turek FW \& Takahashi JS. Mutagenesis and mapping of a mouse gene, Clock, essential for circadian behavior. Science 1994264 719-725. (https://doi. org/10.1126/science.8171325)

20 Dunlap JC. Molecular bases for circadian clocks. Cell 199996 271-290. (https://doi.org/10.1016/S0092-8674(00)80566-8)

21 Lowrey PL \& Takahashi JS. Mammalian circadian biology: elucidating genome-wide levels of temporal organizatio. Annual Review of Genomics and Human Genetics 20045 407-441. (https://doi. org/10.1146/annurev.genom.5.061903.175925)

22 Takahashi JS. Molecular architecture of the circadian clock in mammals. In Research and Perspectives in Endocrine Interactions, pp 13-24. Eds P Sassone-Corsi \& Y Christen. Springer, 2016. (https://doi. org/10.1007/978-3-319-27069-2)

23 Buhr ED \& Takahashi J. Molecular components of the Mammalian circadian clock. Handbook of Experimental Pharmacology 2013217 3-27. (https://doi.org/10.1007/978-3-642-25950-0_1)

24 Partch CL, Green CB \& Takahashi J. Molecular architecture of the mammalian circadian clock. Trends in Cell Biology 201424 90-99. (https://doi.org/10.1016/j.tcb.2013.07.002)

25 Hurley JM, Loros JJ \& Dunlap JC. Circadian oscillators: around the transcription-translation feedback loop and on to output. Trends in Biochemical Sciences 201641 834-846. (https://doi.org/10.1016/j. tibs.2016.07.009)

26 Krieger DT. Food and water restriction shifts corticosterone, temperature, activity and brain amine periodicity. Endocrinology 1974 95 1195-1201. (https://doi.org/10.1210/endo-95-5-1195)

27 Leal ÂMO \& Moreira AC. Feeding and the diurnal variation of the hypothalamic-pituitary-adrenal axis and its responses to CRH and ACTH in rats. Neuroendocrinology 199664 400-403. (https://doi. org/10.1159/000127092)

28 Duffy JF \& Wright KP Jr. Entrainment of the human circadian system by light. Journal of Biological Rhythms 200520 326-338. (https://doi. org/10.1177/0748730405277983)

29 Refinetti R. Comparison of light, food, and temperature as environmental synchronizers of the circadian rhythm of activity in mice. Journal of Physiological Sciences 201565 359-366. (https://doi. org/10.1007/s12576-015-0374-7)

30 Koike N, Yoo SH, Huang HC, Kumar V, Lee C, Kim TK \& Takahashi JS. Transcriptional architecture and chromatin landscape of the core circadian clock in mammals. Science 2012338 349-354. (https://doi. org/10.1126/science.1226339)

31 Takahashi JS. Transcriptional architecture of the mammalian circadian clock. Nature Reviews Genetics 201718 164-179. (https:// doi.org/10.1038/nrg.2016.150)

32 Harfmann BD, Schroder EA \& Esser KA. Circadian rhythms, the molecular clock, and skeletal muscle. Journal of Biological Rhythms 201530 84-94. (https://doi.org/10.1177/0748730414561638)

33 Kiehn J-T, Tsang AH, Heyde I, Leinweber B, Kolbe I, Leliavski A \& Oster H. Circadian rhythms in adipose tissue physiology. 
Comprehensive Physiology 20177 383-427. (https://doi.org/10.1002/ cphy.c160017)

34 Castro M, Elias PC, Martinelli CE Jr, Antonini SR, Santiago L \& Moreira AC. Salivary cortisol as a tool for physiological studies and diagnostic strategies. Brazilian Journal of Medical and Biological Research 200033 1171-1175. (https://doi.org/10.1590/S0100879X2000001000006)

35 Martinelli CE Jr, Yateman ME, Cotterill AM, Moreira AC \& CamachoHübner C. Correlation between cortisol and insulin-like growth factor-binding proteins (IGFBPs) under physiological conditions in children. Clinical Endocrinology 199950 767-774. (https://doi. org/10.1046/j.1365-2265.1999.00724.x)

36 Girotti M, Weinberg MS \& Spencer RL. Diurnal expression of functional and clock-related genes throughout the rat HPA axis: system-wide shifts in response to a restricted feeding schedule. American Journal of Physiology-Endocrinology and Metabolism 2009296 E888-E897. (https://doi.org/10.1152/ajpendo.90946.2008)

37 Lemos DR, Downs JL \& Urbanski HF. Twenty-four-hour rhythmic gene expression in the rhesus macaque adrenal gland. Molecular Endocrinology 200620 1164-1176. (https://doi.org/10.1210/me.20050361)

38 Swaab DF, Fliers E \& Partiman TS. The suprachiasmatic nucleus of the human brain in relation to sex, age and senile dementia Brain Research 1985342 37-44. (https://doi.org/10.1016/00068993(85)91350-2)

39 Welsh DK, Takahashi JS \& Kay SA. Suprachiasmatic nucleus: cell autonomy and network properties. Annual Review of Physiology 201072 551-577. (https://doi.org/10.1146/annurevphysiol-021909-135919)

40 Morin LP. Neuroanatomy of the extended circadian rhythm system. Experimental Neurology 2013243 4-20. (https://doi.org/10.1016/j. expneurol.2012.06.026)

41 Provencio I, Rodriguez IR, Jiang G, Hayes WP, Moreira EF \& Rollag MD. A novel human opsin in the inner retina. Journal of Neuroscience 200020 600-605. (https://doi.org/10.1523/ JNEUROSCI.20-02-00600.2000)

42 La Morgia C, Ross-Cisneros FN, Hannibal J, Montagna P, Sadun AA \& Carelli V. Melanopsin-expressing retinal ganglion cells: implications for human diseases. Vision Research 201151 296-302. (https://doi. org/10.1016/j.visres.2010.07.023)

43 Travnickova-Bendova Z, Cermakian N, Reppert SM \& Sassone-Corsi P. Bimodal regulation of mPeriod promoters by CREB-dependent signaling and CLOCK/BMAL1 activity. PNAS 200299 7728-33. (https://doi.org/10.1073/pnas.102075599)

44 Canteras NS, Ribeiro-Barbosa ÉR, Goto M, Cipolla-Neto J \& Swanson LW. The retinohypothalamic tract: comparison of axonal projection patterns from four major targets. Brain Research Reviews 201165 150-183. (https://doi.org/10.1016/j.brainresrev.2010.09.006)

45 Husse J, Eichele G \& Oster H. Synchronization of the mammalian circadian timing system: light can control peripheral clocks independently of the SCN clock: alternate routes of entrainment optimize the alignment of the body's circadian clock network with external time. BioEssays 201537 1119-1128. (https://doi. org/10.1002/bies.201500026)

46 Watts AG \& Swanson LW. Efferent projections of the suprachiasmatic nucleus: II. Studies using retrograde transport of fluorescent dyes and simultaneous peptide immunohistochemistry in the rat. Journal of Comparative Neurology 1987258 230-252. (https://doi.org/10.1002/ cne.902580205)

47 Hofman MA \& Swaab DF. Alterations in circadian rhythmicity of the vasopressin-producing neurons of the human suprachiasmatic nucleus (SCN) with aging. Brain Research 1994651 134-142. (https:// doi.org/10.1016/0006-8993(94)90689-0)

48 Uhl GR \& Reppert SM. Suprachiasmatic nucleus vasopressin messenger RNA: circadian variation in normal and Brattleboro rats. Science 1986232 390-3. (https://doi.org/10.1126/science.3961487)
49 Maruyama T, Ohbuchi T, Fujihara H, Shibata M, Mori K, Murphy D, Dayanithi G \& Ueta Y. Diurnal changes of arginine vasopressinenhanced green fluorescent protein fusion transgene expression in the rat suprachiasmatic nucleus. Peptides 201031 2089-2093. (https://doi.org/10.1016/j.peptides.2010.08.010)

50 Kalsbeek A, Fliers E, Hofman MA, Swaab DF \& Buijs RM. Vasopressin and the output of the hypothalamic biological clock. Journal of Neuroendocrinology 201022 362-72. (https://doi.org/10.111 $1 / j .1365-2826.2010 .01956)$

51 Perreau-Lenz S, Kalsbeek A, Garidou ML, Wortel J, van der Vliet J, van Heijningen C, Simonneaux V, Pévet P \& Buijs RM. Suprachiasmatic control of melatonin synthesis in rats: inhibitory and stimulatory mechanisms. European Journal of Neuroscience 200317 221-228. (https://doi.org/10.1046/j.1460-9568.2003.02442.x)

52 Pevet P \& Challet E. Melatonin: both master clock output and internal time-giver in the circadian clocks network. Journal of Physiology 2011105 170-182. (https://doi.org/10.1016/j. jphysparis.2011.07.001)

53 Vriend J \& Reiter RJ. Melatonin feedback on clock genes: a theory involving the proteasome. Journal of Pineal Research 201558 1-11. (https://doi.org/10.1111/jpi.12189)

54 Vale W, Spiess J, Rivier C \& Rivier J. Characterization of a 41-residue ovine hypothalamic peptide that stimulates secretion of corticotropin and beta-endorphin. Science 1981213 1394-1397. (https://doi.org/10.1126/science.6267699)

55 Watts AG., Tanimura S \& Sanchez-Watts G. CRH and AVP gene transcription in the hypothalamic paraventricular nucleus of unstressed rats: daily rhythms and their corticosterone dependence. Endocrinology 2004145 529-540. (https://doi.org/10.1210/en.20030394)

56 Plotsky PM, Bruhn TO \& Vale W. Evidence for multifactor regulation of the adrenocorticotropin secretory response to hemodynamic stimuli. Endocrinology 1985116 633-639. (https://doi.org/10.1210/ endo-116-2-633)

57 Aguilera G. Regulation of the hypothalamic-pituitary-adrenal axis by neuropeptides. Hormone Molecular Biology and Clinical Investigation 20117 327-336. (https://doi.org/10.1515/HMBCI.2011.123)

58 Watts AG. Glucocorticoid regulation of peptide genes in neuroendocrine CRH neurons: a complexity beyond negative feedback. Frontiers in Neuroendocrinology 200526 109-130. (https:// doi.org/10.1016/j.yfrne.2005.09.001)

59 Oster H, Challet E, Ott V, Arvat E, de Kloet ER, Dijk DJ, Lightman S, Vgontzas A \& Van Cauter E. The functional and clinical significance of the 24-hour rhythm of circulating glucocorticoids. Endocrine Reviews 201738 3-45. (https://doi.org/10.1210/er.2015-1080)

60 Ur E, Capstick C, McLoughlin L, Checkley S, Michael Besser G \& Grossman A. Continuous administration of human corticotropinreleasing hormone in the absence of glucocorticoid feedback in man. Neuroendocrinology 199561 191-197. (https://doi. org/10.1159/000126840)

61 Engeland WC \& Arnhold MM. Neural circuitry in the regulation of adrenal corticosterone rhythmicity. Endocrine 200528 325-331. (https://doi.org/10.1385/ENDO:28:3:325)

62 Dallman MF, Engeland WC, Rose JC, Wilkinson CW, Shinsako J \& Siedenburg F. Nycthemeral rhythm in adrenal responsiveness to ACTH. American Journal of Physiology 1978235 R210-R218.

63 Ulrich-Lai YM, Arnhold MM \& Engeland WC. Adrenal splanchnic innervation contributes to the diurnal rhythm of plasma corticosterone in rats by modulating adrenal sensitivity to ACTH. American Journal of Physiology, Regulatory, Integrative and Comparative Physiology 2006290 R1128-R1135. (https://doi.org/10.1152/ ajpregu.00042.2003)

64 Bittman EL, Doherty L, Huang L \& Paroskie A. Period gene expression in mouse endocrine tissues. American Journal of Physiology, Regulatory, Integrative and Comparative Physiology 2003285 R561-R569. (https://doi.org/10.1152/ajpregu.00783.2002) 
65 Oster H, Damerow S, Kiessling S, Jakubcakova V, Abraham D, Tian J, Hoffmann MW \& Eichele G. The circadian rhythm of glucocorticoids is regulated by a gating mechanism residing in the adrenal cortical clock. Cell Metabolism 20064 163-173. (https://doi.org/10.1016/j. cmet.2006.07.002)

66 Fahrenkrug J, Hannibal J \& Georg B. Diurnal rhythmicity of the canonical clock genes Per1, Per2 and Bmal1 in the rat adrenal gland is unaltered after hypophysectomy. Journal of Neuroendocrinology 2008 20 323-329. (https://doi.org/10.1111/j.1365-2826.2008.01651.x)

67 Son GH, Chung S, Choe HK, Kim HD, Baik SM, Lee H, Lee HW, Choi S, Sun W, Kim H et al. Adrenal peripheral clock controls the autonomous circadian rhythm of glucocorticoid by causing rhythmic steroid production. PNAS 2008105 20970-20975. (https://doi. org/10.1073/pnas.0806962106)

68 Asai M, Yoshinobu Y, Kaneko S, Mori A, Nikaido T, Moriya T, Akiyama M \& Shibata S. Circadian profile of Per gene mRNA expression in the suprachiasmatic nucleus, paraventricular nucleus, and pineal body of aged rats. Journal of Neuroscience Research 200166 1133-1139. (https://doi.org/10.1002/jnr.10010)

69 Araujo LD, Roa SL, Bueno AC, Coeli-Lacchini FB, Martins CS, Uchoa ET, Antunes-Rodrigues J, Elias LL, Elias PC, Moreira AC et al. Restricted feeding schedules modulate in a different manner the expression of clock genes in rat hypothalamic nuclei. Frontiers in Neuroscience 201610 1-9. (https://doi.org/10.3389/fnins.2016.00567)

70 Chung S, Lee EJ, Cha HK, Kim J, Kim D, Son GH \& Kim K. Cooperative roles of the suprachiasmatic nucleus central clock and the adrenal clock in controlling circadian glucocorticoid rhythm. Scientific Reports 20177 46404. (https://doi.org/10.1038/srep46404)

71 Nader N, Chrousos GP \& Kino T. Interactions of the circadian CLOCK system and the HPA axis. Trends in Endocrinology and Metabolism 201021 277-286. (https://doi.org/10.1016/j. tem.2009.12.011)

72 Spiga F, Walker JJ, Terry JR \& Lightman SL. HPA axis-rhythms. Comprehensive Physiology 20144 1273-1298. (https://doi. org/10.1002/cphy.c140003)

73 Amir S, Lamont EW, Robinson B \& Stewart J. A circadian rhythm in the expression of PERIOD2 protein reveals a novel SCN-controlled oscillator in the oval nucleus of the bed nucleus of the stria terminalis. Journal of Neuroscience 200424 781-790. (https://doi. org/10.1523/JNEUROSCI.4488-03.2004)

74 Soták M, Bryndová J, Ergang P, Vagnerová K, Kvapilová P, Vodička M, Pácha J \& Sumová A. Peripheral circadian clocks are diversely affected by adrenalectomy. Chronobiology International 201633 520-529. (https://doi.org/10.3109/07420528.2016.1161643)

75 Bamberger CM, Bamberger AM, De Castro M \& Chrousos GP. Glucocorticoid receptor $\beta$, a potential endogenous inhibitor of glucocorticoid action in humans. European Journal of Clinical Investigation 199595 2435-2441. (https://doi.org/10.1172/ JCI117943)

76 De Castro M, Elliot S, Kino T, Bamberger C, Karl M, Webster E \& Chrousos GP. The non-ligand binding beta-isoform of the human glucocorticoid receptor (hGR beta): tissue levels, mechanism of action, and potential physiologic role. Molecular Medicine 19962 597-607.

77 Nicolaides NC, Charmandari E, Chrousos GP \& Kino T. Recent advances in the molecular mechanisms determining tissue sensitivity to glucocorticoids: novel mutations, circadian rhythm and ligandinduced repression of the human glucocorticoid receptor. BMC Endocrine Disorders 201414 71. (https://doi.org/10.1186/1472-682314-71)

78 Quax RA, Manenschijn L, Koper JW, Hazes JM, Lamberts SWJ, Van Rossum EFC \& Feelders RA. Glucocorticoid sensitivity in health and disease. Nature Reviews Endocrinology 20139 670-686. (https://doi. org/10.1038/nrendo.2013.183)

79 Nader N, Chrousos GP \& Kino T. Circadian rhythm transcription factor CLOCK regulates the transcriptional activity of the glucocorticoid receptor by acetylating its hinge region lysine cluster: potential physiological implications. FASEB Journal 200923 1572-1583. (https://doi.org/10.1096/fj.08-117697)

80 Lamia KA, Papp SJ, Yu RT, Barish GD, Uhlenhaut NH, Jonker JW, Downes M \& Evans RM. Cryptochromes mediate rhythmic repression of the glucocorticoid receptor. Nature 2011480 552-556. (https://doi.org/10.1038/nature10700)

81 Tomlinson JW, Walker EA, Bujalska IJ, Draper N, Lavery GG, Cooper MS, Hewison M \& Stewart PM. 11beta-hydroxysteroid dehydrogenase type 1: a tissue-specific regulator of glucocorticoid response. Endocrine Reviews 25 831-866. (https://doi.org/10.1210/ er.2003-0031)

82 Di S, Malcher-Lopes R, Halmos KC \& Tasker JG. Nongenomic glucocorticoid inhibition via endocannabinoid release in the hypothalamus: a fast feedback mechanism. Journal of Neuroscience 200323 4850-4857. (https://doi.org/12/23/4850 [pii])

83 Keller-Wood M. Hypothalamic-pituitary-adrenal axis-feedback control. Comprehensive Physiology 20155 1161-1182. (https://doi. org/10.1002/cphy.c140065)

84 Serón-Ferré M, Torres-Farfán C, Forcelledo ML \& Valenzuela GJ. The development of circadian rhythms in the fetus and neonate. Seminars in Perinatology 200125 363-370. (https://doi.org/10.1053/ sper.2001.29037)

85 Sumová A, Bendová Z, Sládek M, El-Hennamy R, Matejů K, Polidarová L, Sosniyenko S \& Illnerová H. Circadian molecular clocks tick along ontogenesis. Physiological Research 200857 (Supplement 3) S139-S148.

86 Sumova A, Sladek M, Polidarova L, Novakova M \& Houdek P. Circadian system from conception till adulthood. Progress in Brain Research 2012199 83-103. (https://doi.org/10.1016/B978-0-44459427-3.00005-8)

87 Christ E, Korf HW \& von Gall C. When does it start ticking? Ontogenetic development of the mammalian circadian system. Progress in Brain Research 2012199 105-118. (https://doi. org/10.1016/B978-0-444-59427-3.00006-X)

88 Serón-Ferré M, Mendez N, Abarzua-Catalan L, Vilches N, Valenzuela FJ, Reynolds HE, Llanos AJ, Rojas A, Valenzuela GJ \& Torres-Farfan C. Circadian rhythms in the fetus. Molecular and Cellular Endocrinology 2012349 68-75. (https://doi.org/10.1016/j. mce.2011.07.039)

89 Swaab DF. Development of the human hypothalamus. Neurochemical Research 199520 509-519. (https://doi.org/10.1007/BF01694533)

90 Dattani MT \& Gevers EF. Endocrinology of fetal development. In Williams Textbook of Endocrinology, 13th ed., ch 22, pp 849-892. Eds S Melmed, KS Polonsky, PR Larsen \& HM Kronenberg. Philadelphia, PA: Elsevier, 2016.

91 Reppert SM \& Schwartz WJ. Functional activity of the suprachiasmatic nuclei in the fetal primate. Neuroscience Letters 1984 46 145-149. (https://doi.org/10.1016/0304-3940(84)90432-4)

92 Hao H \& Rivkees SA. The biological clock of very premature primate infants is responsive to light. Neurobiology 199996 2426-2429. (https://doi.org/10.1073/pnas.96.5.2426)

93 Mirmiran M \& Kok JH. Circadian rhythms in early human development. Early Human Development 199126 121-128. (https:// doi.org/10.1016/0378-3782(91)90016-V)

94 Landgraf D, Koch CE \& Oster H. Embryonic development of circadian clocks in the mammalian suprachiasmatic nuclei. Frontiers in Neuroanatomy 20148 143. (https://doi.org/10.3389/ fnana.2014.00143)

95 Sládek M, Sumová A, Kováčiková Z, Bendová Z, Laurinová K \& Illnerová H. Insight into molecular core clock mechanism of embryonic and early postnatal rat suprachiasmatic nucleus. PNAS 2004101 6231-6236. (https://doi.org/10.1073/pnas.0401149101) 96 Ansari N, Agathagelidis M, Lee C, Korf HW \& von Gall C. Differential maturation of circadian rhythms in clock gene proteins in the suprachiasmatic nucleus and the pars tuberalis during mouse 
ontogeny. European Journal of Neuroscience 200929 477-489. (https:// doi.org/10.1111/j.1460-9568.2008.06605.x.)

$97 \mathrm{Li}$ X \& Davis FC. Developmental expression of clock genes in the Syrian hamster. Brain Research Developmental Brain Research 2005 158 31-40. (https://doi.org/S0165-3806(05)00164-1 [pii] \r10.1016/j. devbrainres.2005.05.005)

98 Houdek P \& Sumová A. In vivo initiation of clock gene expression rhythmicity in fetal rat suprachiasmatic nuclei. PLOS ONE 20149 e107360. (https://doi.org/10.1371/journal.pone.0107360)

99 Bedont JL \& Blackshaw S. Constructing the suprachiasmaticnucleus:a watchmaker's perspective on the central clock works. Frontiers in Systems Neuroscience 20159 1-21. (https://doi.org/10.3389/ fnsys.2015.00074)

100 Torres-Farfan C, Rocco V, Monsó C, Valenzuela FJ, Campino C, Germain A, Torrealba F, Valenzuela GJ \& Seron-Ferre M. Maternal melatonin effects on clock gene expression in a nonhuman primate fetus. Endocrinology 2006147 4618-4626. (https://doi.org/10.1210/ en.2006-0628)

101 Hiroshige T, Honma K \& Watanabe K. Ontogeny of the circadian rhythm of plasma. Journal of Physiology 1982325 493-506.

102 Leal AM, Carvalho J \& Moreira AC. Ontogenetic diurnal variation of adrenal responsiveness to ACTH and stress in rats. Hormone Research 199952 25-29. (https://doi.org/10.1159/000023428)

103 Roa SLR, Martinez EZ, Martins CS, Antonini SR, De Castro M \& Moreira AC. Postnatal ontogeny of the circadian expression of the adrenal clock genes and corticosterone rhythm in male rats. Endocrinology 2017158 1339-1346. (https://doi.org/10.1210/ en.2016-1782)

104 Champagne FA \& Curley JP. Epigenetic mechanisms mediating the long-term effects of maternal care on development. Neuroscience and Biobehavioral Reviews 200933 593-600. (https://doi.org/10.1016/j. neubiorev.2007.10.009)

105 Rowe SA \& Kennaway DJ. Melatonin in rat milk and the likelihood of its role in postnatal maternal entrainment of rhythms. American Journal of Physiology, Regulatory, Integrative and Comparative Physiology 2002282 R797-R804. (https://doi.org/10.1152/ajpregu.00228.2001)

106 Torres-Farfan C, Mendez N, Abarzua-Catalan L, Vilches N, Valenzuela GJ \& Seron-Ferre M. A circadian clock entrained by melatonin is ticking in the rat fetal adrenal. Endocrinology $2011 \mathbf{1 5 2}$ 1891-1900. (https://doi.org/10.1210/en.2010-1260)

107 Mendez N, Abarzua-Catalan L, Vilches N, Galdames HA, Spichiger C, Richter HG, Valenzuela GJ, Seron-Ferre M \& TorresFarfan C. Timed maternal melatonin treatment reverses circadian disruption of the fetal adrenal clock imposed by exposure to constant light. PLoS ONE 20127 e42713. (https://doi.org/10.1371/ journal.pone.0042713)

108 Yamazaki S, Yoshikawa T, Biscoe EW, Numano R, Gallaspy LM, Soulsby S, Papadimas E, Pezuk P, Doyle SE, Tei H et al. Ontogeny of circadian organization in the rat. Journal of Biological Rhythms 2009 24 55-63. (https://doi.org/10.1177/0748730408328438)

109 Serón-Ferré M, Riffo R, Valenzuela GJ \& Germain AM. Twentyfour-hour pattern of cortisol in the human fetus at term. American Journal of Obstetrics and Gynecology 2001184 1278-1283. (https://doi. org/10.1067/mob.2001.113322)

110 Bettendorf M, Albers N, Bauer J, Heinrich UE, Linderkamp O \& Maser-Gluth C. Longitudinal evaluation of salivary cortisol levels in full-term and preterm neonates. Hormone Research 199850 303-308.

111 Klug I, Dressendörfer R, Strasburger C, Kühl GP, Reiter HL, Reich A, Müller G, Meyer K, Kratzsch J \& Kiess W. Cortisol and 17-Hydroxyprogesterone levels in saliva of healthy neonates. Biology of the Neonate 200078 22-26. (https://doi.org/10.1159/000014242)

112 Iwata O, Okamura H, Saitsu H, Saikusa M, Kanda H, Eshima N, Iwata S, Maeno Y \& Matsuishi T. Diurnal cortisol changes in newborn infants suggesting entrainment of peripheral circadian clock in utero and at birth. Journal of Clinical Endocrinology and Metabolism 201398 E25-E32. (https://doi.org/10.1210/jc.2012-2750)
113 Vermes I, Dohanics J, Tóth G \& Pongrácz J. Maturation of the circadian rhythm of the adrenocortical functions in human neonates and infants. Hormone Research 198012 237-244. (https://doi. org/10.1159/000179126)

114 Mantagos S, Moustogiannis A \& Vagenakis AG. Diurnal variation of plasma cortisol levels in infancy. Journal of Pediatric Endocrinology and Metabolism 199811 549-553. (https://doi.org/10.1515/ JPEM.1998.11.4.549)

115 Francis SJ, Walker RF, Riad-Fahmy D, Hughes D, Murphy JF \& Gray OP. Assessment of adrenocortical activity in term newborn infants using salivary cortisol determinations. Journal of Pediatrics 1987111 129-133. (https://doi.org/10.1016/S0022-3476(87)80359-1)

116 Price DA, Close GC \& Fielding BA. Age of appearance of circadian rhythm in salivary cortisol values in infancy. Archives of Disease in Childhood 198358 454-456. (https://doi.org/10.1136/adc.58.6.454)

117 Santiago LB, Jorge SM \& Moreira AC. Longitudinal evaluation of the development of salivary cortisol circadian rhythm in infancy. Clinical Endocrinology 199644 157-161. (https://doi.org/10.1046/j.13652265.1996.645466.x)

118 De Weerth C, Zijl RH \& Buitelaar JK. Development of cortisol circadian rhythm in infancy. Early Human Development $2003 \mathbf{7 3}$ 39-52. (https://doi.org/10.1016/S0378-3782(03)00074-4)

119 Ivars K, Nelson N, Theodorsson A, Theodorsson E, Ström JO \& Mörelius E. Development of salivary cortisol circadian rhythm and reference intervals in full-term infants. PLoS ONE 201510 1-15. (https://doi.org/10.1371/journal.pone.0129502)

120 Calixto C, Martinez FE, Jorge SM, Moreira AC \& Martinelli CE. Correlation between plasma and salivary cortisol levels in preterm infants. Journal of Pediatrics 2002140 116-118. (https://doi. org/10.1067/mpd.2002.120765)

121 Maas C, Ringwald C, Weber K, Engel C, Poets CF, Binder G \& Bassler D. Relationship of salivary and plasma cortisol levels in preterm infants: results of a prospective observational study and systematic review of the literature. Neonatology 2014105 312-318. (https://doi.org/10.1159/000357555)

122 Antonini SRR, Jorge SM \& Moreira AC. The emergence of salivary cortisol circadian rhythm and its relationship to sleep activity in preterm infants. Clinical Endocrinology 200052 423-426. (https://doi. org/10.1111/j.1365-2265.2000.tb00561.x)

123 Ivars K, Nelson N, Theodorsson A, Theodorsson E, Ström JO \& Mörelius E. Development of salivary cortisol circadian rhythm in preterm infants. PLoS ONE 201712 e0182685. (https://doi. org/10.1371/journal.pone.0182685)

124 Custodio RJ, Martinelli CE, Milani SLS, Simões AL, De Castro M \& Moreira AC. The emergence of the cortisol circadian rhythm in monozygotic and dizygotic twin infants: the twin-pair synchrony. Clinical Endocrinology 200766 192-197. (https://doi.org/10.1111/ j.1365-2265.2006.02706.x)

125 Watamura SE, Donzella B, Kertes DA \& Gunnar MR. Developmental changes in baseline cortisol activity in early childhood: relations with napping and effortful control. Developmental Psychobiology 2004 45 125-133. (https://doi.org/10.1002/dev.20026)

126 Clow A, Hucklebridge F \& Thorn L. The cortisol awakening response in context. International Review of Neurobiology 201093 153-175. (https://doi.org/10.1016/S0074-7742(10)93007-9)

127 Krieger DT, Allen W, Rizzo F \& Krieger HP. Characterization of the normal temporal pattern of plasma corticosteroid levels. Journal of Clinical Endocrinology and Metabolism 197132 266-284. (https://doi. org/10.1210/jcem-32-2-266)

128 Weitzman ED, Fukushima D, Nogeire C, Roffwarg H, Gallagher TF $\&$ Hellman L. Twenty-four hour pattern of the episodic secretion of cortisol in normal subjects. Journal of Clinical Endocrinology and Metabolism 197133 14-22. (https://doi.org/10.1210/jcem-33-1-14)

$129 \mathrm{Llu} \mathrm{JH}$, Kazerj RR \& Rasmussen DD. Characterization of the twentyfour hour secretion patterns of adrenocorticotropin and cortisol in normal women and patients with Cushing's disease. Journal of 
Clinical Endocrinology and Metabolism 198764 1027-1035. (https:// doi.org/10.1210/jcem-64-5-1027)

130 Veldhuis JD, Iranmanesh A, Lizarralde G \& Johnson ML. Amplitude modulation of a burstlike mode of cortisol secretion subserves the circadian glucocorticoid rhythm. American Journal of Physiology 1989257 E6-E14. (https://doi.org/doi.org/10.1152/ ajpendo.1989.257.1.E6)

131 Yang S, Liu A, Weidenhammer A, Cooksey RC, McClain D, Kim MK, Aguilera G, Abel ED \& Chung JH. The role of mPer2 clock gene in glucocorticoid and feeding rhythms. Endocrinology 2009150 2153-2160. (https://doi.org/10.1210/en.2008-0705)

132 Dallmann R, Touma C, Palme R, Albrecht U \& Steinlechner S. Impaired daily glucocorticoid rhythm in Per1Brdmice. Journal of Comparative Physiology A: Neuroethology, Sensory, Neural, and Behavioral Physiology 2006192 769-775. (https://doi.org/10.1007/s00359-0060114-9)

133 Stewart PM, Penn R, Gibson R, Holder R, Parton A, Ratcliffe JG \& London DR. Hypothalamic abnormalities in patients with pituitary-dependent Cushing's syndrome. Clinical Endocrinology 1992 36 453-458. (https://doi.org/10.1111/j.1365-2265.1992.tb02245.x)

134 Boyar RM, Witkin M, Carruth A \& Ramsey J. Circadian cortisol secretory rhythms in Cushing's disease. Journal of Clinical Endocrinology and Metabolism 197948 760-765. (https://doi.org/10.1210/jcem-48-5-760)

135 Liddle GW. Tests of pituitary-adrenal suppressibility in the diagnosis of Cushing's syndrome. Journal of Clinical Endocrinology and Metabolism 196020 1539-1560. (https://doi.org/10.1210/jcem-20-121539)

136 Castro M, Elias LLK, Elias PCL \& Moreira AC. A dose-response study of salivary cortisol after dexamethasone suppression test in Cushing's disease and its potential use in the differential diagnosis of Cushing's syndrome. Clinical Endocrinology 200359 800-805. (https://doi. org/10.1046/j.1365-2265.2003.01908.x)

137 Ray DW, Davis JR, White A \& Clark AJ. Glucocorticoid receptor structure and function in glucocorticoid-resistant small cell lung carcinoma cells. Cancer Research 199656 3276-3280. (https://doi. org/10.1210/mend.9.9.7491111)

138 Dahia PL, Aguiar RC, Honegger J, Fahlbush R, Jordan S, Lowe DG, Lu X, Clayton RN, Besser GM \& Grossman AB. Mutation and expression analysis of the p27/kip1 gene in corticotrophin-secreting tumours. Oncogene 199816 69-76. (https://doi.org/10.1038/ sj.onc.1201516)

139 Antonini SR, Latronico AC, Elias LL, Cukiert A, Machado HR, Liberman B, Mendonca BB, Moreira AC \& Castro M. Glucocorticoid receptor gene polymorphisms in ACTH-secreting pituitary tumours. Clinical Endocrinology 200257 657-662.

140 Glass AR, Zavadil AP, Halberg F, Cornelissen G \& Schaaf M. Circadian rhythm of serum cortisol in Cushing's disease. Journal of Clinical Endocrinology and Metabolism 198459 161-165. (https://doi. org/10.1210/jcem-59-1-161)

141 Vagnucci AH. Analysis of circadian periodicity of plasma cortisol in normal man and in Cushing's syndrome. American Journal of Physiology 1979236 R268-R281. (https://doi.org/10.1152/ ajpregu.1979.236.5.R268)

142 van Cauter E \& Refetoff S. Evidence for two subtypes of Cushing's disease based on the analysis of episodic cortisol secretion. New England Journal of Medicine 1985312 1343-1349. (https://doi. org/10.1056/NEJM198505233122102)

143 Castro M, Elias PCL, Quidute ARP, Halah FPB \& Moreira AC. Outpatient screening for Cushing's syndrome: the sensitivity of the combination of circadian rhythm and overnight dexamethasone suppression salivary cortisol tests. Journal of Clinical Endocrinology and Metabolism 199984 878-882. (https://doi.org/10.1210/ jcem.84.3.5521)

144 Yanovski JA, Nieman LK, Doppman JL, Chrousos GP, Wilder RL, Gold PW \& Kalogeras KT. Plasma levels of corticotropin-releasing hormone in the inferior petrosal sinuses of healthy volunteers, patients with Cushing's syndrome, and patients with pseudoCushing states. Journal of Clinical Endocrinology and Metabolism 1998 83 1485-1488. (https://doi.org/10.1210/jc.83.5.1485)

145 Kling MA, DeBellis MD, O'Rourke DK, Listwak SJ, Geracioti TD Jr, McCutcheon IE, Kalogeras KT, Oldfield EH \& Gold PW. Diurnal variation of cerebrospinal fluid immunoreactive corticotropinreleasing hormone levels in healthy volunteers. Journal of Clinical Endocrinology and Metabolism 199479 233-239. (https://doi. org/10.1210/jcem.79.1.8027234)

146 Garrick NA, Hill JL, Szele FG, Tomai TP, Gold PW \& Murphy DL. Corticotropin-releasing factor: a marked circadian rhythm in primate cerebrospinal fluid peaks in the evening and is inversely related to the cortisol circadian rhythm. Endocrinology 1987121 1329-1334. (https://doi.org/10.1210/endo-121-4-1329)

147 Kling MA, Roy A, Doran AR, Calabrese JR, Rubinow DR, Whitfield HJ, May C, Post RM, Chrousos GP \& Gold PW. Cerebrospinal fluid immunoreactive cortieotropin-releasing hormone and adrenocorticotropin secretion in Cushing's disease and major depression: potential clinical implications. Journal of Clinical Endocrinology and Metabolism 199172 260-271. (https://doi. org/10.1210/jcem-72-2-260)

148 Tomori N, Suda T, Tozawa F, Demura H, Shizume K \& Mouri T. Immunoreactive corticotropin-releasing factor concentrations in cerebrospinal fluid from patients with hypothalamic-pituitaryadrenal disorders. Journal of Clinical Endocrinology and Metabolism 198357 1305-1307. (https://doi.org/10.1210/jcem-57-6-1305)

149 Van Wijk PA, Rijnberk A, Croughs RJM, Voorhout G, Sprang EPM \& Mol JA. Corticotropin-releasing hormone and adrenocorticotropic hormone concentrations in cerebrospinal fluid of dogs with pituitary-dependent hyperadrenocorticism. Endocrinology 1992131 2659-2662. (https://doi.org/10.1210/endo.131.6.1332844)

150 Terzolo M, Piovesan A, Alì A, Codegone A, Pia A, Reimondo G, Torta M, Paccotti P, Borretta G \& Angeli A. Circadian profile of serum melatonin in patients with Cushing's syndrome or acromegaly. Journal of Endocrinological Investigation 199518 17-24. (https://doi. org/10.1007/BF03349691)

151 de Castro M \& Moreira AC. Screening and diagnosis of Cushing's syndrome. Arquivos Brasileiros de Endocrinologia and Metabologia 200751 1191-1198. (https://doi.org/10.1590/S000427302007000800004)

152 Nieman LK, Biller BMK, Findling JW, Newell-Price J, Savage MO, Stewart PM \& Montori VM. The diagnosis of Cushing's syndrome: an Endocrine Society clinical practice guideline. Journal of Clinical Endocrinology and Metabolism 200893 1526-1540. (https://doi. org/10.1210/jc.2008-0125)

153 Guignat L \& Bertherat J. The diagnosis of Cushing's syndrome: an Endocrine Society clinical practice guideline: commentary from a European perspective. European Journal of Endocrinology 2010163 9-13. (https://doi.org/10.1530/EJE-09-0627)

154 Valassi E, Franz H, Brue T, Feelders RA, Netea-Maier R, Tsagarakis S, Webb SM, Yaneva M, Reincke M, Droste M et al. Diagnostic tests for Cushing's syndrome differ from published guidelines: data from ERCUSYN. European Journal of Endocrinology 2017176 613-624. (https://doi.org/10.1530/EJE-16-0967)

155 Walker RF, Riad-Fahmy D \& Read GF. Adrenal status assessed by direct radioimmunoassay of cortisol in whole saliva or parotid saliva. Clinical Chemistry 197824 1460-1463.

156 Luthold WW, Marcondes JAM \& Wajchenberg BL. Salivary cortisol for the evaluation of Cushing's syndrome. Clinica Chimica Acta 1985 151 33-39. (https://doi.org/10.1016/0009-8981(85)90232-3)

157 Laudat MH, Cerdas S, Fournier C, Guiban D, Guilhaume B \& Luton JP. Salivary cortisol measurement: a practical approach to assess pituitary-adrenal function. Journal of Clinical Endocrinology and Metabolism 198866 343-348. (https://doi.org/10.1210/jcem-66-2-343)

158 Raff H, Raff JL \& Findling JW. Late-night salivary cortisol as a screening test for Cushing's syndrome. Journal of Clinical 
Endocrinology and Metabolism 199883 2681-2686. (https://doi. org/10.1210/jc.83.8.2681)

159 Papanicolaou DA, Mullen N, Kyrou I \& Nieman LK. Nighttime salivary cortisol: a useful test for the diagnosis of Cushing's syndrome. Journal of Clinical Endocrinology and Metabolism 200287 4515-4521. (https://doi.org/10.1210/jc.2002-020534)

160 Putignano P, Toja P, Dubini A, Pecori Giraldi F, Corsello SM \& Cavagnini F. Midnight salivary cortisol versus urinary free and midnight serum cortisol as screening tests for Cushing's syndrome. Journal of Clinical Endocrinology and Metabolism 200388 4153-4157. (https://doi.org/10.1210/jc.2003-030312)

161 Trilck M, Flitsch J, Lüdecke D, Jung R \& Petersenn S. Salivary cortisol measurement - a reliable method for the diagnosis of Cushing's syndrome. Experimental and Clinical Endocrinology and Diabetes 2005 113 225-230. (https://doi.org/10.1055/s-2005-837667)

162 Yaneva M, Mosnier-Pudar H, Dugué MA, Grabar S, Fulla Y \& Bertagna X. Midnight salivary cortisol for the initial diagnosis of Cushing's syndrome of various causes. Journal of Clinical Endocrinology and Metabolism 200489 3345-3351. (https://doi. org/10.1210/jc.2003-031790)

163 Martinelli CE Jr, Sader SL, Oliveira EB, Daneluzzi JC \& Moreira AC. Salivary cortisol for screening of Cushing's syndrome in children. Clinical Endocrinology 199951 67-71. (https://doi.org/10.1046/ j.1365-2265.1999.00749.x)

164 Gafni RI, Papanicolaou DA \& Nieman LK. Nighttime salivary cortisol measurement as a simple, noninvasive, outpatient screening test for Cushing's syndrome in children and adolescents. Journal of Pediatrics 2000137 30-35. (https://doi.org/10.1067/mpd.2000.106226)

165 Carroll T, Raff H \& Findling J. Late-night salivary cortisol for the diagnosis of Cushing syndrome: a meta-analysis. Endocrine Practice 200915 335-342. (https://doi.org/10.4158/EP09023OR)
166 Zhang Q, Dou J, Gu W, Yang G \& Lu J. Reassessing the reliability of the salivary cortisol assay for the diagnosis of Cushing syndrome. Journal of International Medical Research 201341 1387-1394. (https:// doi.org/10.1177/0300060513498017)

167 Raff H. Update on late-night salivary cortisol for the diagnosis of Cushing's syndrome: methodological considerations. Endocrine 2013 44 346-349. (https://doi.org/10.1007/s12020-013-0013-0)

168 Elias PCL, Martinez EZ, Barone BFC, Mermejo LM, Castro M \& Moreira AC. Late-night salivary cortisol has a better performance than urinary free cortisol in the diagnosis of Cushing's syndrome. Journal of Clinical Endocrinology and Metabolism 201499 2045-2051. (https://doi.org/10.1210/jc.2013-4262)

169 Danet-Lamasou M, Asselineau J, Perez P, Vivot A, Nunes ML, Loiseau H, San-Galli F, Cherifi-Gatta B, Corcuff JB \& Tabarin A. Accuracy of repeated measurements of late-night salivary cortisol to screen for early-stage recurrence of Cushing's disease following pituitary surgery. Clinical Endocrinology 201582 260-266. (https:// doi.org/10.1111/cen.12534)

170 Pruessner JC, Wolf OT, Hellhammer DH, Buske-Kirschbaum A, Von AuerK, Jobst S, Kaspers F \& Kirschbaum C. Free cortisol levels after awakening: a reliable biological marker for the assessment of adrenocortical activity. Life Sciences 199761 2539-2549. (https://doi. org/10.1016/S0024-3205(97)01008-4)

171 Clow A, Thorn L, Evans P \& Hucklebridge F. The awakening cortisol response: methodological issues and significance. Stress 20047 29-37. (https://doi.org/10.1080/10253890410001 667205)

172 Roa SLR, Elias PCL, Castro M \& Moreira AC. The cortisol awakening response is blunted in patients with active Cushing's disease. European Journal of Endocrinology 2013168 657-664. (https://doi. org/10.1530/EJE-12-0982)

Received 6 February 2018

Revised version received 5 April 2018

Accepted 16 April 2018 